\title{
KARMELICI BOSI W KRĘGU ZAINTERESOWAŃ APARATU BEZPIECZEŃSTWA PRL NA TERENIE WOJEWÓDZTWA KRAKOWSKIEGO W ŚWIETLE ZACHOWANYCH SPRAWOZDAŃ KIEROWANYCH DO MBP I MSW W LATACH 1947-1970
}

W dniu 21 lipca 1944 roku ustawą wydaną przez Krajową Radę Narodowa o utworzeniu Polskiego Komitetu Wyzwolenia Narodowego został powołany Resort Bezpieczeństwa Publicznego. Jego zadania i działalność były w całej rozciągłości wzorowane na radzieckim NKWD. Resort ten - wszelkimi środkami - miał chronić „władzę ludowa”, zlikwidować opozycję polityczną i zbrojne podziemie, utrwalić nowy system polityczno-spoleczno-gospodarczy, rozbić Kościół katolicki $i$ inne zwiazki wyznaniowe. Resortowi podlegała Milicja Obywatelska, Korpus Bezpieczeństwa Wewnętrznego, więzienia oraz obozy pracy. Z dniem 1 stycznia 1945 roku został przekształcony w Ministerstwo Bezpieczeństwa Publicznego. W jego ramach działał w Departamencie V Wydzial V, który zajmował się inwigilowaniem Kościoła katolickiego. Reorganizacja Ministerstwa w 1949 roku doprowadziła do utworzenia Departamentu XI, którego zadaniem był nadzór nad Kościołem katolickim. Kolejna reorganizacja MBP miala miejsce w grudniu 1954 roku. Powstał wówczas Komitet do Spraw Bezpieczeństwa Publicznego oraz Ministerstwo Spraw Wewnętrznych. Sprawami Kościoła zajmował się Departament VI Komitetu oraz Wydział V (od 1962 roku Departament IV) Ministerstwa. W listopadzie 1956 roku dokonano kolejnej reorganizacji aparatu bezpieczeństwa, zmieniając nazwę nazwę „Urząd Bezpieczeństwa” (UB) na „Służbę Bezpieczeństwa" (SB). Dotychczasową działalność Komitetu do Spraw Bezpieczeństwa Publicznego przejęło zreorganizowane Ministerstwo Spraw Wewnętrznych. Departament IV zakończył działalność w 1990 roku ${ }^{1}$.

Pierwsze komórki służby bezpieczeństwa na terenie województwa krakowskiego, w tym także Sekcja V zajmująca się rozpracowaniem Kościola katolickiego, powstały w styczniu 1945 roku wraz z wejściem do Krakowa armii radzieckiej. Brak materiałów archiwalnych nie pozwala na pełne odtworzenie działalności UB w środowisku kościelnym na terenie województwa krakowskiego. Kierownikami Sekcji V byli kolejno, od 1946 roku, Stanisław Lipski i Józef Matwiszyn,

Szerzej na ten temat zob. H. D o m in i c zak, Organy bezpieczeństwa PRL $w$ walce z Kościołem katolickim 1944-1990. W'swietle dokumentów MSW, Warszawa 2000, s. $13 \mathrm{n}$. 
którego w marcu lub kwietniu 1948 roku zastapił Krzysztof Srokowski. Przeprowadzono wówczas reorganizację pracy i zapowiedziano pełniejsze niż dotychczas i bardziej właściwe wykorzystanie materiałów na kler diecezjalny i zakonny. Jak wynika z późniejszych sprawozdań opracowano zapewne instrukcje (kwestionariusze) relacji okresowych ${ }^{2}$.

Funkcjonariusze krakowskiego WUBP byli świadomi, że działają na terenie, na którym przebywa znaczna liczba duchowieństwa. Dlatego też systematycznie budowali agenturę. W pierwszej połowie 1948 roku na terenie województwa krakowskiego spośród kleru diecezjalnego było 5 agentów i jeden informator, z którymi zorganizowano 13 spotkań. Ponadto przyjęto 10 doniesień. W analogicznym okresie spośród kleru zakonnego było 2 agentów, z którymi odbyło się 2 spotkania. Kierownicy krakowskiej Sekcji V WUBP uważali, że liczba pozyskanych współpracowników była niewystarczająca ${ }^{3}$.

Pod koniec 1948 roku zauważa się intensyfikację działalności na polu infiltracji środowisk zakonnych przez pracowników powiatowych i wojewódzkich urzędów Bezpieczeństwa Publicznego. Kierownik Sekcji V Wydziału V WUBP w Krakowie Krzysztof Srokowski w sprawozdaniu do Wydziału V Departamentu V MBP w grudniu 1948 roku ubolewał, że agentura wśród kleru zakonnego ${ }^{4}$ jest niedostatecznie obsadzona, mimo, że w stosunku do czerwca liczba informatorów spośród kleru diecezjalnego wzrosła do 6 a spośród zakonnego do $5^{5}$.

W 1950 roku odszedł z Wydziału XI (do 1949 roku Sekcja V) WUBP w Krakowie na wyższe stanowisko wspomniany wyżej Srokowski a jego obowiązki przejał Stanisław Florek (początkowo jako p.o. kierownika Sekcji). Pod jego kierownictwem prowadzono intensywną kampanię walki z Kościołem katolickim. Od lutego 1953 roku sprawy zakonne na terenie województwa krakowskiego prowadził starszy referent chor. Wincenty Piechowicz.

Po 1950 roku agentura krakowskich służb bezpieczeństwa byla znacznie rozbudowana. W czerwcu 1953 roku WUBP w Krakowie miał wśród zakonników 1 agenta, 30 informatorów i 3 mieszkania konspiracyjne, a spośród zakonnic 9 informatorek i 2 mieszkania konspiracyjne, natomiast powiatowe urzędy Bezpieczeństwa Publicznego wśród zakonników posiadały 19 informatorów a spośród zakonnic - 3 informatorki ${ }^{6}$.

${ }^{2}$ Por. Instytut Pamięci Narodowej. Oddziałowe Biuro Udostępniania i Archiwizacji Dokumentów w Krakowie (dalej: IPNKr), sygn. 039/1, t. 1, Sprawozdanie kierownika Sekcji V Wydzialu V K. Srokowskiego [?] do MBP Departamentu V Wydziału V, Kraków, 30 VI 1948 r., s. 136.

${ }^{3}$ Por. tamże, Raport okresowy p.o. kierownika Sekcji V Wydzialu V do MBP Departamentu V Wydziału V, Kraków, 5 VI 1948 r., s. 130.

${ }^{4}$ Warto odnotować je w latach $1949-1951$ szefowie Sekrij V Wydzialu V WURP w Krakowie w swe sprawozdania dzielili na dzialy: kler świecki, „Caritas”, kler pozytywny, stowarzyszenia katolickie, organizacje katolickie; brak jest działu „kler zakonny”, który pojawia się dopiero w lutym 1953 roku. Obiekty zakonne prowadził wówczas na terenie województwa krakowskiego st. ref, chor. W. Piechowicz. Brak sprawozdań z działu „kler zakonny” może sugerować, że zostały wyłączone z ogólnych sprawozdań lub przekazane w całości do szczególnych zadań operacyjnych.

${ }^{5}$ Por. IPNKr, sygn. 039/1, t. 1, Sprawozdanie kierownika Sekcji V Wydziału V K. Srokowskiego do MBP Departamentu V Wydziału V, Kraków, [XII] 1948 r., s. 195-196.

${ }^{6}$ Por. tamze, t. 3, Sprawozdanie p.o. kierownika ppor. Z. Faryny z pracy Sekcji II Wydziatu XI WUBP w Krakowie za okres I-30 VI 1953 roku do naczelnika Wydziatu II Departamentu XI MBP w Warszawie, Kraków, 4 VII 1953 r. (ściśle tajne), s. 78. 
W marcu 1954 roku liczba konfidentów zakonnych nieznacznie się zmniejszyła. Sekcja II Departamentu VI (wcześniej Wydział XI) WUBP w Krakowie miała 1 agenta, 23 informatorów i 4 mieszkania konspiracyjne, a spośród zakonnic 5 informatorek i 2 mieszkania konspiracyjne, natomiast urzędy powiatowe BP wśród zakonników posiadały 20 informatorów a spośród zakonnic -4 informatorki. W październiku t.r. było w WUBP 20 informatorów męskich zakonnych i 5 lokali konspiracyjnych, 13 informatorów żeńskich (zakonnice) i 2 lokale, natomiast w PUBP - 22 męskich informatorów zakonnych i 3 zakonnice?

Trudno jest ustalić powody, którymi kierowała się Sekcja II (sprawy zakonne) Wydziału XI WUBP w Krakowie w doborze wspólnot zakonnych i poddawaniu tylko niektórych z nich szczególnemu opracowaniu. W miesięcznych sprawozdaniach naczelnika Wydziału XI WUBP w Krakowie za rok 1954 niektóre zakony bądź zgromadzenia występują regularnie, może uważane za niebezpieczne, a inne sporadycznie (zob. Tabela I). Zapewne niektóre ze wspólnot uważano za szczególnie niebezpieczne.

Tabela I. Inwigilacja męskich wspólnot zakonnych w 1954 roku przez WUBP w Krakowie

\begin{tabular}{|c|c|c|c|c|c|c|c|c|c|c|c|c|c|}
\hline \multirow{2}{*}{ Lp. } & \multirow{2}{*}{ Wspólnoty zakonne } & \multicolumn{12}{|c|}{ Rok 1954} \\
\hline & & I & II & III & IV & $\mathrm{V}$ & VI & VII & VIII & IX & $\mathrm{X}$ & $\mathrm{XI}$ & XII \\
\hline 1 & benedyktyni & & + & & + & & & + & + & + & + & + & + \\
\hline 2 & bernardyni & & & + & & & & + & + & & & & \\
\hline 3 & bonifratrzy & & & & & & & & & & & \pm & \\
\hline 4 & cystersi & + & + & + & + & + & + & + & + & + & & + & + \\
\hline 5 & dominikanie & $t$ & & & & & & & & & & & \\
\hline 6 & franciszkanie & & & & & & & & & + & & & \\
\hline 7 & jezuici & & & + & + & + & + & + & + & + & + & + & + \\
\hline 8 & kanonicy regularni & & & + & & & & & & & & & \\
\hline 9 & karmelici bosi & & & + & + & & & + & & & + & & \\
\hline 10 & michalici & & & & & & & & & & & + & \\
\hline 11 & misjonarze & & + & + & + & + & + & + & & + & + & + & + \\
\hline 12 & pijarzy & + & & & & + & + & + & & & & & \\
\hline 13 & reformaci & & & & & + & + & + & + & & & & \\
\hline 14 & saletyni & & & & & & & + & & & & & \\
\hline 15 & salezjanie & & & & + & + & + & + & + & + & + & + & + \\
\hline 16 & salwatorianie & & & & & & & & & & + & + & + \\
\hline 17 & sercanie & & & & & & + & & & + & + & & \\
\hline
\end{tabular}

Źródlo: Instytut Pamięci Narodowej. Oddzialowe Biuro Udostępniania i Archiwizacji Dokumentów w Krakowie, sygn. 03\%/1, t. 4, Sprawozdanie kpt. Z.Glinskiego naczelnika Wydzialu XI WUBP w Krakowie za miesiąc styczeń 1954 roku do Dyrektora Departamentu XI MBP w Warszawie, Kraków, 1954 r. (ściśle tajne), s. 190-191; tamże, Sprawozdanie kpt. Z. Glinskiego naczelnika Wydziahu XI WUBP w Krakowie za miesiac luty 1954 roku do Dyrektora Departamentu XI MBP w Warszawie, Kraków, 1954 r. (ściśle tajne), s. 206-208; tamze, Sprawozdanie kpt. Publicznego Z. Glinskiego naczelnika Wydzialu XI WUBP w Krakowie za miesiac marzec 1954 roku do Dyrektora Departamentu XI MBP w Warszawie, Kraków, 7 IV 1954 r. (ściśle tajne), s. 227-230; tamże, Sprawozdanie kpt. Publicznego Z. Glinskiego naczelnika Wydziału XI WUBP

${ }^{7}$ Por. tamże, t. 3, Sprawozdanie kierownika ppor. Z. Faryny z pracy Sekcji II Wydziatu XI WUBP w Krakowie za okres 1-3I III 1954 roku do naczelnika Wydziatu II Departamentu XI MBP w Warszawie, Kraków, 31 III 1954 r. (ściśle tajne), s. 209; Tamże, Sprawozdanie kierownika por. Z. Faryny z pracy Sekcji II Wydziatu XI WUBP w Krakowie za okres 1-3I X 1954 roku do naczelnika Wydziału II Departamentu XI MBP w Warszawie, Kraków, 3 XI 1954 r. (ściśle tajne), s. 327. 
w Krakowie za miesiac kwiecien 1954 roku do Dyrektora Departamentu XI MBP w Warszawie, Kraków, 1954 r. (ściśle tajne), s. 249-254; Sprawozdanie kpt. Publicznego Z. Glińskiego naczelnika Wydzialu XI WUBP w Krakowie za miesiac maj 1954 roku do Dyrektora Departamentu XI MBP w Warszawie, Kraków, 1954 r. (ściśle tajne), s. 271-276; tamże, Sprawozdanie por. Publicznego S. Florka naczelnika Wydziatu XI WUBP w Krakowie za miesiac czerwiec 1954 roku do Dyrektora Departamentu XI MBP w Warszawie, Kraków, 12 VIl 1954 r. (ściśle tajne), s. 293-299; tamze, Sprawozdanie por. S. Florka naczelnika Wydziatu XI WUBP w Krakowie za miesiac lipiec 1954 roku do Dyrektorn Departamentu XI MBP w Warszawie, Kraków, 6 VIII 1954 r. (ściśle tajne), s. 312-318; tamże, Sprawozdanie por. S. Florka naczelnika Wydzialu XI WUBP w Krakowie za miesiac sierpień 1954 roku do Dyrektora Departamentu XI MBP w Warszawie, Kraków, 6 IX 1954 r. (ściśle tajne), s. 335-340; tamże, Sprawozdanie por. S. Florka naczelnika Wydzialu XI WUBP W Krakowie za miesiąc wrzesień 1954 roku do Dyrektora Departamentu XI MBP w Warszawie, Kraków, 6 X 1954 r. (ściśle tajne), s. 356-358; tamże, Sprawozdanie por. S. Florka naczelnika Wydzialu XI WUBP $w$ Krakowie za miesiąc październik 1954 roku do Dyrektora Departamentu XI MBP w Warszawie, Kraków, 6 XI 1954 r. (ściśle tajne), s. 374-378; tamże, Sprawozdanie por. S. Florka naczelnika Wydzialu XI WUBP w Krakowie za miesiac listopad 1954 roku do Dyrektora Departamentu XI MBP w Warszawie, Kraków, 6 XII 1954 r. (ściśle tajne), s. 393-398; tamże, Sprawozdanie por. S. Florka naczelnika Wydziału XI WUBP w Krakowie za miesiąc grudzień 1954 roku do Dyrektora Departamentu XI MBP w Warszawie, Kraków, 8 I 1955 r. (ściśle tajne), s. 415-418.

Celem intensyfikacji działań w 1955 roku utworzono w obrębie Wydziału VI WUBP w Krakowie Sekcję IIa, która zajmowała się wspólnotami zakonnymi żeńskimi. Jej etatowymi pracownikami byli: por. Zbigniew Faryna - kierownik sekcji, chor. Henryk Król, ppor. Józef Chojnicki, st. sierz. Ludwik Kuciel. Wspólnotami męskimi zajmowała się Sekcja $\mathrm{II}^{8}$.

Połowa lat pięćdziesiątych charakteryzowała się dalszym wzrostem zainteresowania służb bezpieczeństwa środowiskami zakonnymi. W dniu 1 stycznia 1955 roku na terenie województwa krakowskiego spośród klenı zakonnego do współpracy z UB zaangażowanych było: 19 informatorów oraz jeden agent. Korzystano także z 5 lokali konspiracyjnych. Rok później wśród duchownych konfidentów było: 2 agentów (obaj zakonnicy) i 20 informatorów (w tym 9 zakonników), którzy korzystali do kontaktów z funkcjonariuszami UB z 3 lokali konspiracyjnych. Dla porównania, w dniu 24 czerwca 1958 roku było 2 agentów, 38 informatorów oraz 6 lokali konspiracyjnych ${ }^{9}$.

W trzecim kwartale 1962 roku agentura kościelna (kler zakonny i diecezjalny) na terenie województwa krakowskiego liczyła 57 informatorów (tajnych współpracowników), 12 lokali konspiracyjnych i 3 mieszkania konspiracyjne. W opracowaniu było 48 kandydatów na tajnych współpracowników spośród zakonników i kapłanów diecezjalnych. Podczas kolejnej reorganizacji Wydziału IV Służby Bezpieczeństwa Komendy Wojewódzkiej MO (w połowie 1962 roku) utworzono cztery grupy operacyjne: kler diecezjalny - I, kler zakonny - II, świecki aktyw katolicki - III, świadkowie Jehowy oraz inne wyznania niekatolickie - IV ${ }^{10}$.

${ }^{8}$ Zob. tamże, t. 7, Sprawozdanie naczelnika Wydzialu VI kpt. S. Florka i por. Z. Faryny kierownika Sekcji II z pracy Sekcji II Wydzialu VI WU ds. BP w Krakowie za okres od dnia IIV 1955 do dnia 30 IV 1955 do naczelnika Wydzialu II Departamentu VI Komitetu ds. BP w Warszawie, Kraków, 5 V 1955 r. (ściśle tajne), s. 48.

${ }^{9}$ Por. tamże, Ocena pracy Sekcji II Wydziału VI za rok 1955 i zadania na najbliższy okres, Kraków, 2 III 1956 r. (ściśle tajne), s. 261-263; Tamże, t. 9, Sprawozdanie z pracy Grup V i Va Wydzialu III KWMO w Krakowie za okres II-go kwartatu 1958 roku do naczelnika Wydziału V Departamentu III MSW w Warszawie, Kraków, 23 VI 1958 r. (ściśle tajne), s. 166.

${ }^{10}$ Por. tamże, t. 10, Sprawozdanie z pracy operacyjnej Wydzialu IV SB KWMO w Krakowie za III-ci kwartal 1962 roku, Kraków, 1962 r. (ściśle tajne), s. 29, 31, 40. 
Pod koniec 1962 roku pracowało w Wydziale IV w Krakowie 27 osób. Na czele Wydziału stał mjr Z. Gliński, a jego zastępcami byli mjr Z. Faryna i kpt. S. Tyrpa. Kierownikiem Grupy I był porucznik J. Biel, który kierował ośmioosobowym zespołem. Kierownikiem Grupy II był kpt. P. Lebiedź. Ponadto pracowali jako starsi oficerowie operacyjni: kpt. J. Chojnacki, por. H. Król, ppor. W. Kupka i por. T. Pączek oraz oficerowie operacyjni: plut. J. Frydrych i S. sierż. W. Biel i sierż. R. Surma, który został zwolniony z pracy w dniu 31 grudnia 1962 roku. Grupą III kierował por. J. Schiller, którego wspomagał ppor. S. Malik a Grupą IV - kpt. D. Dudek, dwóch którym współpracowało dwóch oficerów operacyjnych. W Sekretariacie pracowała E. Gaździk (sekretarka) i M. Buchalska (maszynistka), jako kierowca zatrudniony był J. Chytry ${ }^{11}$.

Dwa lata później, w 1964 roku, Wydział IV zatrudniał 32 osoby: 8 pracowników operacyjnych dla rozpracowania działalności biskupów, kurii diecezjalnych w Krakowie i w Tarnowie, seminariów duchownych i uczelni katolickich; 2 pracowników operacyjnych dla rozpracowania działalności parafii i kleru w miastach wojewódzkich; 10 pracowników operacyjnych dla rozpracowania kleru zakonnego; 3 pracowników - dla katolików świeckich; 3 pracowników dla wyznań niekatolickich; 6 pracowników (w tym 3 sekretarki) dla prowadzenia analiz i sprawozdawczości ${ }^{12}$.

W 1964 roku Grupa II prowadziła 436 teczek na kapłanów zakonnych i 341 na alumnów zakonnych. Ponadto nadzorowała 29 spraw „,wytypowanych do rozpracowania” i 25 spraw „aktywnego rozpracowania”. Były także obserwacje i inne operacje $^{13}$.

W połowie lat sześćdziesiątych roku wzmożono wysiłki celem dalszej penetracji środowisk kościelnych i zakonnych oraz pozyskania tajnych współpracowników. „Opracowywano” także kandydatów na współpracowników. W Sprawozdaniu z 1965 roku zaznaczono, że ,Wydział IV ponad 1/3 opracowywanych kandydatów umiejscowił wśród: 4 kurialistów; 8 profesorów WSD; 1 prowincjała; 8 przełożonych klasztorów i domów zakonnych"14.

Trudno jest na obecnym etapie badań ustalić listę funkcjonariuszy służby bezpieczeństwa na poziomie powiatów. W 1964 roku sprawami Kościoła katolickiego w powiecie chrzanowskim zajmowal się starszy oficer operacyjny ppor. W. Chmielowski (kontaktował się z 9 tajnymi wspólpracownikami i prowadził 60 teczek personalnych kapłanów oraz 29 teczek parafialnych) i starszy oficer operacyjny por. P. Zatylny (kontaktował się z 4 tajnymi współpracownikami, opracowywał 4 kandydatów, prowadził 70 teczek księży, w tym 26 dla kapłanów zakonnych i 35 teczek na braci zakonnych oraz 9 na alumnów) ${ }^{15}$.

" Por. tamże, Sprawozdanie z pracy operacyjnej Wydziału IV SB KWMO w Krakowie za III-ci kwartal 1962 roku, Kraków, 1962 r. (ściśle tajne). Faktyczny stan pracowników Wydziatu IV-go SB KWMO w Krakowie, Kraków, 10 X 1962 r., s. 41.

${ }_{12}$ Por. tamże, t. 12, Sprawozdanie z pracy operacyjnej Wydziału IV SB KWMO w Krakowie za rok 1964, Kraków, 9 I 1965 r. (tajne specjalnego znaczenia), s. 77.

${ }^{13}$ Por. tamże, t. 13, cz. 1, Sprawozdanie z pracy operacyjnej Grupy II Wydziatu IV-go za rok 1964, Kraków, 31 XII 1964 r. (tajne specjalnego znaczenia), s. 86.

${ }^{14}$ Tamże, t. 12, Sprawozdanie z pracy pionu IV-go SB KWMO w Krakowie za rok 1965, Kraków, 7 I 1964 r. (tajne specjalnego znaczenia), s. 112.

${ }^{15}$ Por. tamże, t. 14, Sprawozdanie [Komendy Powiatowej MO w Chrzanowie] za rok 1964 po zagadnieniu Wydziału IV-go, Chrzanów, XII 1964 r. (tajne), s. 151. 
Po II wojnie światowej teren województwa krakowskiego kilkakrotnie zmieniał swój zasięg. W latach 1945-1975 obejmował, oprócz miasta Krakowa, powiaty: bialski i bialski grodzki (powiaty te zostały właczone w 1951 roku do województwa katowickiego), bocheński, brzeski, chrzanowski, dąbrowski, jasielski (włączony w sierpniu 1945 roku do województwa rzeszowskiego), krakowski, krakowski grodzki, limanowski, miechowski, myślenicki, nowosądecki, nowotarski, olkuski, oświęcimski (powstały w 1951 roku), proszowicki (powstały w 1954 roku), suski (powstały w 1955 roku), tarnowski, wadowicki, żywiecki; ponadto w jego skład wchodzily od 1951 roku powiaty grodzkie (miejskie): Nowy Sacz, Tarnów i Zakopane a od 1956 roku Jaworzno. Przez cały omawiany okres wielokrotnie prowadzono korekty granic województwa ${ }^{16}$.

W 1954 roku Kraków zyskał status miasta wydzielonego. Warto dodać, że kolejne zmiany terytorialne województwa krakowskiego miały miejsce w 1975 i 1999 roku. W ostatnim z wymienionych przywrócono podział na powiaty, które to struktury zlikwidowano w 1975 roku. Początkowo władzę sprawował wojewoda, od 1949 roku, w miejsce wojewody, prezydium Wojewódzkiej Rady Narodowej, a od 1973 roku znów wojewoda i Urząd Wojewódzki ${ }^{17}$.

W dniu 31 grudnia 1946 roku województwo krakowskie liczyło $15918 \mathrm{~km}$ kw. i 2133400 mieszkańców, z których 579800 (27,2\% ogółu mieszkańców województwa) mieszkało w 43 miastach. W końcu 1968 roku województwo krakowskie obejmowało $15356 \mathrm{~km} \mathrm{kw.} \mathrm{i} 2185500$ mieszkańców, z których 651100 $(29,8 \%)$ mieszkalo w miastach ${ }^{18}$.

Państwowy podział administracyjny nie pokrywał się w omawianym okresie z podziałem kościelnym. Obszar województwa krakowskiego rozciagał się na teren archidiecezji krakowskiej, częściowo na tereny diecezji tarnowskiej, kieleckiej i katowickiej. Teren województwa krakowskiego należał do nielicznych w kraju, na którym w stosunku do powierzchni jak i do liczby mieszkańców znajdowała się znaczna liczba zakonnych domów generalnych, prowincjalnych, formacyjnych oraz wyższych i niższych seminariów. Tym samym liczba zakonników i sióstr zakonnych była znaczna. Dla przykładu, bez wnikania w dokładne dane, należy wspomnieć, że na terenie miasta Krakowa na przełomie 1962/1963 roku funkcjonowało 34 domy zakonne męskie i 74 żeńskie. Przy 10 domach męskich były prowadzone parafie. Ponadto $w$ dwóch parafiach zakonnicy pracowali jako wikariusze. Sześć zakonów i zgromadzeń męskich prowadziło nowicjaty (bonifratrzy, cystersi, dominikanie, bernardyni, kameduli, misjonarze); ponadto funkcjonowały postulaty. W omawianym okresie 17 wspólnot zakonnych prowadziło w Krakowie seminaria duchowne (jezuici, salezjanie, misjonarze, paulini, franciszkanie, karmelici bosi, kapucyni, reformaci, zmartwychwstańcy, sercanie, dominikanie, pijarzy, kanonicy regułarni, michalici, karmelici trzewiczkowi, saletyni oraz cystersi. Było też jedno niższe seminarium prowadzone przez misjonarzy na ul. Stradom.

${ }^{16}$ Zgodnie z ustawą z 20 III 1950 r. WRN stała się organem terenowym władzy państwowej, a jej prezydium organem zarządzającym województwem i władzą administracyjną drugiej instancji; zniesiono także wówczas stanowisko wojewody krakowskiego. Por. Województwo krakowskie, [w:] Encyklopedia Krakowa, Warszawa-Kraków 2000, s. 1061.

${ }_{17}^{17}$ Por. tamze, s. 1061.

18 Por. Rocznik statystyczny 1947, Warszawa 1947, s. 14-15, 18; Rocznik statystyczny 1969, Warszawa 1969, s. 29. 
Tabela II. Liczba domów żeńskich wspólnot zakonnych na terenie archidiecezji krakowskiej w latach 1949, 1958, 1972

\begin{tabular}{|c|c|c|c|c|c|}
\hline Lp. & Nazwa wspólnoty zakonnej & 1949 & 1958 & 1972 & Uwagi \\
\hline 1 & adoratorki & \multicolumn{2}{|c|}{-} & 1 & \\
\hline 2 & albertynki & 11 & 10 & 12 & \\
\hline 3 & antoninki & \multicolumn{2}{|c|}{-} & 1 & \\
\hline 4 & augustianki & 3 & 2 & 3 & \\
\hline 5 & benedyktynki & 1 & 1 & 1 & \\
\hline 6 & bernardynki & 1 & 1 & 1 & \\
\hline 7 & boromeuszki & 1 & 2 & 2 & \\
\hline 8 & córki Bożej Miłości & 5 & 5 & 7 & \\
\hline 9 & dominikanki (czynne) & - & 2 & 1 & \\
\hline 10 & dominikanki klauzurowe & 1 & 1 & 1 & \\
\hline 11 & duchaczki & 2 & 5 & 7 & \\
\hline 12 & elżbietanki & - & 1 & 2 & \\
\hline 13 & felicjanki & 20 & 21 & 21 & \\
\hline 14 & franciszkanki od cierpiących & - & 1 & 1 & \\
\hline 15 & franciszkanki od wieczystej adoracji & 1 & 1 & l & \\
\hline 16 & franciszkanki służebnice Krzyża & \multicolumn{2}{|c|}{-} & 1 & \\
\hline 17 & honoratki & - & 2 & 1 & \\
\hline 18 & józefitki & 1 & 2 & 5 & \\
\hline 19 & karmelitanki bose & 4 & 3 & 3 & \\
\hline 20 & karmelitanki od Dzieciątka Jezus & 2 & 4 & 5 & \\
\hline 21 & klaryski & 1 & 1 & 1 & \\
\hline 22 & klawerianki & - & 1 & - & \\
\hline 23 & michalitki & - & 2 & 3 & \\
\hline 24 & misjonarki Swiętej Rodziny & \multicolumn{2}{|c|}{-} & 1 & \\
\hline 25 & nazaretanki & 5 & 2 & 4 & \\
\hline 26 & niepokalanki & 1 & 1 & 3 & \\
\hline 27 & norbertanki & 2 & 2 & 2 & \\
\hline 28 & pasjonistki & 2 & 2 & 2 & \\
\hline 29 & pocieszycielki & \multicolumn{2}{|c|}{-} & 1 & \\
\hline 30 & prezentki & 2 & 3 & 3 & \\
\hline 31 & salezjanki & - & 2 & 2 & \\
\hline 32 & salwatorianki & - & 3 & 5 & \\
\hline 33 & serafitki & 22 & 28 & 25 & \\
\hline 34 & sercanki & 4 & 8 & 6 & \\
\hline 35 & siostry Bożej Opatrzności & - & 1 & 1 & \\
\hline 36 & siostry Imienia Jezus & - & 1 & 1 & \\
\hline 37 & siostry Matki Bożej Miłosierdzia & 3 & 3 & 3 & \\
\hline 38 & siostry Najczystszego Serca NMP & - & 1 & 1 & \\
\hline 39 & siostry Najśw. Duszy Chrystusa Pana & - & 8 & 11 & \\
\hline 40 & siostry Notre Dame & - & l & 1 & \\
\hline 41 & siostry od Aniołów & 1 & \multicolumn{2}{|c|}{-} & \\
\hline 42 & siostry Rodziny Maryi & 8 & 14 & 10 & \\
\hline 43 & siostry Sacre Coeur & 1 & \multicolumn{2}{|c|}{-} & \\
\hline 44 & siostry Wspólnej Pracy & - & 1 & 1 & \\
\hline 45 & sługi Jezusa & - & 2 & 2 & \\
\hline 46 & sługi Maryi & - & 1 & 1 & \\
\hline 47 & służebnice Najśw. Serca Pana Jezusa & - & 1 & - & \\
\hline 48 & służebniczki dębickie & - & 10 & 8 & \\
\hline 49 & służebniczki starowiejskie & 41 & 38 & 31 & \\
\hline
\end{tabular}




\begin{tabular}{|l|l|c|c|c|c|}
\hline 50 & służebniczki wielkopolskie & 1 & 1 & 1 & \\
\hline 51 & słuzki NMP & - & 1 & 2 & \\
\hline 52 & szarytki & 19 & 22 & 21 & \\
\hline 53 & urszulanki & 1 & 2 & 2 & \\
\hline 54 & urszulanki Unii Rzymskiej & 4 & 3 & 3 & \\
\hline 55 & wizytki & 1 & 1 & 1 & \\
\hline 56 & zmartwychwstanki & 4 & 5 & 7 & \\
\hline \multicolumn{2}{|l}{ RAZEM } & $\mathbf{1 7 6}$ & $\mathbf{2 3 6}$ & $\mathbf{2 4 3}$ & \\
\hline
\end{tabular}

Źródło: Elenchus venerabilis cleni Archidioeceseos Cracoviensis pro Anno 1949, Cracoviae 1949, s. 199_ -208; Katalog kościolow i duchowieństwa Archidiecezji Krakowskiej. 1958, Kraków 1958, s. 325-352; Katalog kościolów i duchowieństwa Archidiecezji Krakowskiej.1972, Kraków 1972, s. 395-426.

W 1962 roku na terenie archidiecezji krakowskiej było 474 kapłanów, 392 kleryków, 177 braci zakonnych, 31 nowicjuszy oraz 15 postulantów i aspirantów. W parafiach administrowanych przez zakonników pracowało 33 kapłanów (10 proboszczów, 18 wikariuszy i 5 rezydentów). Zakonnicy prowadzili przy parafiach 11 punktów katechetycznych a przy klasztorach -12 .

Tabela III. Męskie wspólnoty zakonne na terenie archidiecezji krakowskiej w latach 1949, 1958, 1972

\begin{tabular}{|c|c|c|c|c|c|c|c|c|c|c|c|c|c|c|}
\hline \multirow[b]{2}{*}{ Lp. } & \multirow[b]{2}{*}{$\begin{array}{l}\text { Wspólnoty } \\
\text { zakonne }\end{array}$} & \multicolumn{6}{|c|}{1949} & \multicolumn{5}{|c|}{1958} & \multirow{2}{*}{\begin{tabular}{|c|}
1972 \\
房 \\
\end{tabular}} & \multirow[b]{2}{*}{ UWAGI } \\
\hline & & ह & $\frac{\bar{g}}{\bar{s}}$ & $\frac{2}{2}$ & 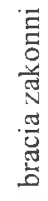 & 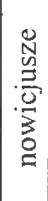 & 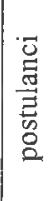 & 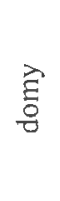 & $\begin{array}{l}\overline{\bar{g}} \\
\overline{\bar{g}} \\
\underline{\bar{g}}\end{array}$ & $\left|\begin{array}{l}\vec{J} \\
\grave{d} \\
\stackrel{\vec{\omega}}{\Xi}\end{array}\right|$ & 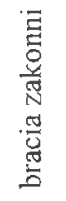 & 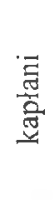 & & \\
\hline 1 & albertyni & 3 & \multicolumn{5}{|c|}{$\mathrm{bd}$} & 4 & - & - & 20 & $\mathrm{bd}$ & 3 & \\
\hline 2 & augustianie & 2 & 8 & - & 3 & - & - & \multicolumn{5}{|c|}{-} & - & \\
\hline 3 & benedyktyni & 1 & 9 & 8 & 5 & - & - & 1 & 12 & - & 17 & bd & 1 & \\
\hline 4 & bernardyni & 4 & 32 & 5 & 17 & - & 7 & 4 & 34 & 54 & 23 & $\mathrm{bd}$ & 4 & \\
\hline 5 & bonifratrzy & 3 & 1 & - & 55 & bd & - & 3 & 4 & - & 44 & bd & 4 & \\
\hline 6 & cystersi & 1 & 10 & 1 & 3 & bd & - & $1+3$ & 22 & 20 & 7 & $\mathrm{bd}$ & $1+1$ & \\
\hline 7 & dominikanie & 1 & 17 & 16 & 16 & 12 & 4 & 1 & 21 & 53 & 14 & bd & 2 & \\
\hline 8 & franciszkanie & 3 & 19 & 10 & 17 & - & - & 3 & 27 & 99 & 14 & bd & 5 & \\
\hline 9 & jezuici & 5 & 61 & 2 & 23 & - & - & 4 & 58 & - & 30 & bd & 4 & \\
\hline 10 & kameduli & 1 & 10 & - & 16 & 4 & - & 1 & 10 & 2 & 13 & bd & 1 & \\
\hline 11 & kanonicy lat. & 2 & 8 & 2 & 7 & - & - & 2 & 14 & - & 8 & bd & 2 & \\
\hline 12 & kapucyni & 2 & 13 & 7 & 10 & - & - & 4 & 20 & 27 & 9 & bd & 4 & \\
\hline 13 & karmelici bosi & 4 & 34 & 13 & 19 & 5 & 3 & 5 & 39 & 27 & 29 & bd & 5 & $\begin{array}{c}\text { NSD } \\
\text { Wadowice: } \\
84 \text { uczniów } \\
\text { (1949 r.) }\end{array}$ \\
\hline 14 & karmelici trzew. & 2 & 9 & 2 & 9 & 3 & - & 2 & 11 & 24 & 8 & bd & 2 & \\
\hline 15 & Marianie & \multicolumn{11}{|c|}{-} & $1+4$ & \\
\hline 16 & michalici & 3 & \multicolumn{5}{|c|}{ bd } & 2 & 15 & 26 & 4 & 12 & 2 & \\
\hline 17 & misjonarze & 8 & 59 & 42 & 22 & bd & - & 4 & 55 & - & 13 & $\mathrm{bd}$ & 5 & \\
\hline 18 & oblaci & \multicolumn{6}{|c|}{-} & 1 & 2 & - & - & - & - & \\
\hline 19 & orioniści & \multicolumn{11}{|c|}{-} & 1 & \\
\hline 20 & palotyni & 1 & 10 & - & 10 & - & - & 2 & 10 & - & 11 & bd & 2 & \\
\hline 21 & paulini & 1 & 12 & 13 & 6 & - & - & 2 & 6 & 58 & 6 & $\mathrm{bd}$ & 2 & \\
\hline 22 & pijarzy & 2 & 18 & & bd & & - & 3 & 26 & 19 & 10 & bd & 5 & \\
\hline 23 & redemptoryści & 1 & 10 & - & 4 & - & - & 1 & 10 & - & 3 & 8 & 1 & \\
\hline
\end{tabular}




\begin{tabular}{|c|c|c|c|c|c|c|c|c|c|c|c|c|c|c|}
\hline 24 & reformaci & 6 & 28 & 5 & 18 & - & - & $5+4$ & 27 & 38 & 16 & 8 & 6 & \\
\hline 25 & saletyni & \multicolumn{6}{|c|}{-} & 2 & 4 & 13 & 1 & $b d$ & 3 & \\
\hline 25 & salezjanie & \multicolumn{6}{|c|}{ - } & 14 & 57 & 135 & 26 & bd & \begin{tabular}{|c|}
$7+1$ \\
3
\end{tabular} & \\
\hline 27 & salwatorianie & 1 & 5 & - & 3 & - & - & 4 & 26 & 26 & 5 & $\mathrm{bd}$ & 4 & \\
\hline 28 & sercance & 1 & \multicolumn{5}{|c|}{ bd } & $3+2$ & 30 & 37 & 5 & 13 & $4+1$ & $\begin{array}{c}\text { NSD } \\
\text { Stadniki: } \\
32(1958 \text { r.) }\end{array}$ \\
\hline 29 & werbiści & \multicolumn{6}{|c|}{-} & 1 & 1 & - & - & - & - & \\
\hline 30 & $\begin{array}{l}\text { zmartwych- } \\
\text { wstańcy }\end{array}$ & 1 & 7 & 6 & 8 & - & - & $2+1$ & 12 & - & 3 & 15 & $4+1$ & \\
\hline & RAZEM & in & $\infty$ & జ్ & $\underset{N}{\mathbb{N}}$ & $\pi$ & I & $\stackrel{+}{\infty}=$ & $\underset{n}{\infty}$ & $\infty_{n}^{\infty}$ & 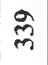 & in & ${ }_{\infty}^{+} \underset{\infty}{\infty}$ & \\
\hline
\end{tabular}

Źródło: Elenchus venerabilis cleri Archidioeceseos Cracoviensis pro Anno 1949, Cracoviae 1949, s. 185-199; Katalog kościolów $i$ duchowieństwa Archidiecezji Krakowskiej. 1958, Kraków 1958, s. 312-324; Katalog kościolów i duchowieństwa Archidiecezji Krakowskiej 1972, Kraków 1972, s. 380-394.

Na terenie miasta Krakowa we wrześniu 1964 roku było 32 żeńskie zgromadzenia zakonne (72 domy z 1813 siostrami zakonnymi. Na terenie województwa było 54 zgromadzenia ( 291 domów, 2691 sióstr). Na terenie miasta i województwa było 10 domów generalnych żeńskich i 10 prowincjalnych. W dwa lata później (1964) na terenie miasta i województwa było 2 domy generalne, 29 kurii prowincjalnych, 6 opactw i domów autonomicznych, 14 zakonnych seminariów duchownych, 50 parafii prowadzonych przez zakonników ${ }^{19}$.

Imponująca była praca sióstr zakonnych na terenie miasta Krakowa (zob. Tabela IV). Zakonnice prowadziły liczne dzieła miłosierdzia, przedszkola, angażowały się w działalność katechetyczna, pracowały w kancelariach, na plebaniach i w świątyniach jako zakrystianki i organistki. Prezentki prowadziły liceum z 252 uczennicami. Nowych miejsc pracy poszukiwało także na terenie miasta około 170 sióstr zakonnych zwolnionych z zakładów Zrzeszenia "Caritas”.

Tabela IV. Działalność charytatywna sióstr zakonnych na terenie miasta Krakowa (1962)

\begin{tabular}{|c|c|c|c|c|}
\hline \multirow[b]{2}{*}{ Lp. } & \multirow[b]{2}{*}{ Zgromadzenie } & \multirow[b]{2}{*}{ Prowadzone dzieło } & \multicolumn{2}{|c|}{ Liczba } \\
\hline & & & $\begin{array}{l}\text { pod- } \\
\text { opiecz- } \\
\text { nych }\end{array}$ & sióstr \\
\hline 1 & córki Bożej Miłości & zakład specjalny dla dzieci („Caritas”) & 40 & 16 \\
\hline \multirow[t]{4}{*}{2} & \multirow{4}{*}{ felicjanki } & Zakład Społeczny dla Przewlekle Chorych & 110 & 13 \\
\hline & & zakład leczniczo-wychowawczy & 30 & 8 \\
\hline & & zakład wychowawczy dla upośledzonych & 50 & 10 \\
\hline & & internat dla uczennic & 50 & 3 \\
\hline \multirow[t]{2}{*}{3} & \multirow{2}{*}{$\begin{array}{l}\text { służebniczki } \\
\text { staromiejskie }\end{array}$} & zakład wychowawczy dla upośledzonych umyslowo & 35 & 8 \\
\hline & & zakład wychowawczy dla upośledzonych umysłowo & 35 & 8 \\
\hline 4 & szarytki & Zakład Swiętej Rodziny & 50 & 9 \\
\hline & RAZEM & 400 & 75 \\
\hline
\end{tabular}

Źródło: Instytut Pamięci Narodowej. Oddziałowe Biuro Udostępniania i Archiwizacji Dokumentów w Krakowie, sygn. 08/141 t. 1, s. 65-70a: Dane statystyczne dotyczace zgromadzeń zakonnych na terenie miasta Krakowa - stan na dzień 31 III $1963 \mathrm{r}$.

${ }^{19}$ Por. IPNKr, sygn. 08/141, t. 1, Wniosek o przyznanie Grupie II Wydział IV 3-ch etatów, Kraków, 11 VII 1966 r, s. 147. 
Pierwsze wzmianki w zachowanych i obecnie dostępnych materiałach aparatu bezpieczeństwa $\mathrm{z}$ terenu województwa krakowskiego dotyczące karmelitów bosych pochodzą z 1947 roku. Wówczas to założono „obiekt” na karmelitów bosych i trzewiczkowych o kryptonimie „K.B.”. Majqc dane agenturalne jak też sprawozdania $z$ kazań oraz ich wrogq odnoszqca się działalność do obecnego ustroju jako zakony o charakterze nauczań kazaniowych, założono na w/w zakony [salezjanie, salwatorianie, karmelici, karmelici bosi, misjonarze i redemptoryści] obiekty ${ }^{20}$. W roku tym przystapiono do szczegółowego rozpracowania środowisk zakonnych. Podjęto próby pozyskiwania współpracowników spośród zakonników. Dla ówczesnej władzy i aparatu bezpieczeństwa „wszystkie metody były dozwolone". Kilkumiesięczna obserwacja klasztorów, gromadzenie i systematyzowanie informacji o poszczególnych zakonnikach - o ich przeszłości wojennej, słabościach i grzechach, przyzwyczajeniach, kontaktach z osobami świeckimi, analiza kazań i wypowiedzi na tematy społeczno-polityczne były cennymi źródłami. Innym źródłem wiadomości było przyjmowanie donosów od samych zakonników (najczęściej skonfliktowanych $\mathrm{z}$ własnym środowiskiem) lub osób świeckich skłóconych z zakonnikami lub niezadowolonych $\mathrm{z}$ ich postępowania.

Aktywność krakowskich służb bezpieczeństwa w rozpracowywaniu środowisk zakonnych po 1947 roku nie ominęła karmelitów bosych. K. Srokowski w jednym ze sprawozdań zaznaczył: Odnośnie kleru zakonnego zaplanowaliśmy werbunek [...] przeora klasztoru z pow. Wadowickiego. Wszyscy w/w będa werbowani na materiatach kompr[omitujacych] moralnych za utrzymywanie stosunków intymnych z kobietami, z wyjatkiem przeora klasztoru z pow. Wadowice, który wspótpracowat z bandq. ${ }^{21}$.

Nie tylko referenci WUBP, którzy swoimi działaniami wspomagali pracowników urzędów powiatowych, interesowali się środowiskiem karmelitów bosych $\mathrm{i}$ ich działalnością duszpasterską. W dniu 29 stycznia 1949 roku nieznany z nazwiska starszy referen z WUBP w Krakowie, na wyraźne polecenie MBP wyjechał do Czernej w celu ustalenia powodów prowadzenia kursu, sposobów i metod działalności Żywego Różańca Dziewczą ${ }^{22}$.

Kolejna informacja o ,opracowywaniu" karmelitów bosych na terenie województwa krakowskiego pochodzi z października 1950 roku. Jak można się domyślać, był to efekt szczególnego interesowania się zakonem przez UB. W jesieni 1950 roku na materiałach kompromitujących zwerbowano informatora ps. „Gienio". Nie kolaborowal zbyt długo z krakowskim UB, gdyż po kilku tygodniach ów informator został, decyzją władz zakonnych, przeniesiony poza Kraków ${ }^{23}$.

${ }^{20}$ Tamże, sygn. 039/1, t. 1, Pismo kierownika Sekcji V Wydziału V J. Matwiszyna do MBP Departamentu V Wydziału V, Kraków, 19 III 1947 r., s. 7.

${ }^{21}$ Tamże, Sprawozdanie kierownika Sekcji V..., Kraków, [XII] 1948 r., s. 199.

22 Por. tamże, Sprawozdanie kierownika Sekcji V...Kraków, 5 II 1949 r., s. 209.

${ }^{23}$ Por. tamże, t. 2, Sprawozdanie kierownika Sekcji V Wydzialu V K. Srokowskiego do naczelnika Wydzialu V Departanentu MBP w Warszawie, Kraków, 6 X 1950 r., s. 66; tamże, Sprawozdanie z pracy Sekcji 5 Wydziatu V WUBP w Krakowie za miesiac listopad 1950 roku do naczelnika Wydzialu V Departamentu MBP w Warszawie, Kraków, XI 1950 r., s. 87; J. Marecki, Wykaz wspótpracowników stuzby bezpieczeństwa PRL spośród osób zakonnych na terenie województwa krakowskiego [msps], Kraków, s. 10. 
Prawdopodobnie w roku 1951 został pozyskany do współpracy informator ps. „Satyr". Po przeniesieniu go przez władze zakonne na teren Polski centralnej nadal był aktywnym współpracownikiem $\mathrm{UB}^{24}$. Około 1958 roku (lub wcześniej) powrócił na teren województwa krakowskiego i nadal aktywnie uczestniczył w pracy agentury.

Jak to było w praktyce, oficerowie WUBP w Krakowie przesłali teczki personalne a i zapewne materiały, które od informatorów od chwili rozpoczęcia współpracy pozyskali, do WUBP, na teren których zostali przeniesieni. Należy dodać, że UB nigdy nie rezygnowało $z$ pozyskanego współpracownika. Kiedy ów opuszczał teren zamieszkania, wędrowały za nim jego akta personalne i oświadczenia o podjęciu współpracy, kiedy kategorycznie odmawiał przekazywania informacji i wypełniania zadań to szantażowano go „kompromitującymi materiałami" lub ujawnieniem współpracy. Niekiedy, gdy informator był mało przydatny, zawieszano współpracę z nim, akta personalne archiwizowano i cierpliwie czekano na rozwój wypadków. Znane są z terenu krakowskiego przypadki, że pracownicy Służby Bezpieczeństwa powracali z żądaniem do odnowienia współpracy z byłymi tajnymi współpracownikami po przerwach trwających 10-15 lat.

Wynikiem dalszej szczegółowej penetracji środowiska karmelitańskiego było aresztowanie w listopadzie 1950 roku o. Korneliusza Franciszka Ziębę z krakowskiego klasztoru karmelitów bosych ,za rozsiewanie wrogiej propagandy przeciwko Polsce Ludowej i ZSRR" $"$.

W 1950 roku, jak wspomniano wyżej, Sekcję V objął Stanisław Florek, który z wielkim zaangażowaniem poświęcił się pracy nad pozyskaniem nowych współpracowników ze środowiska zakonnego. Osobiście wyjeżdżal w teren, aby typować tzw. figurantów na tajnych współpracowników oraz nadzorować opracowywanie planów pracy i walki z zakonami w PUBP. I tak na przykład w dniach 12-13 września 1951 roku przebywał w terenie celem nawiązania kontaktu $z$ zakonnikiem oznaczonym pseudonimem ,D" $\mathrm{z}$ tamtejszego klasztoru karmelitów bosych ${ }^{26}$.

W czerwcu następnego roku (4-5 VI 1952) starszy referent ppor. Zbigniew Faryna przebywał w PUBP w Wadowicach celem pomocy w rozpoznaniu tamtejszych niższych seminariów zakonnych. Na terenie powiatu wadowickiego funkcjonowały wówczas małe seminaria w Kalwarii Zebrzydowskiej (bernardyni) oraz w Wadowicach (pallotyni i karmelici bosi) ${ }^{27}$.

Zainteresowanie się klasztorem wadowickim karmelitów bosych przez Urząd Bezpieczeństwa wynikało zapewne i stąd, że karmelici bosi byli mocno zaangażowani w działalność rekolekcyjno-misyjną a przez to byli opiniotwórczy w środowisku klerykalnym. Funkcjonariusze UB z trwogą odnotowywali w swych sprawozdaniach wzmożoną działalność duszpasterską (zwłaszcza rekolekcyjno-

${ }^{24}$ Por. IPNKr, sygn. 039/1, t. 2, Sprawozdanie z pracy Sekcji $V$ Wydziatu V WUBP w Krakowie za miesiac maj 1951 roku do naczelnika Wydziatu V Departamentu MBP $w$ Warszawie, Kraków, V 1951 r. (ściśle tajne), s. 135.

${ }_{25}$ Por. tamże, Sprawozdanie... za miesiac listopad 1950 roku..., s. 88.

${ }^{26}$ Por. tamże, Sprawozdanie z pracy Sekcji V Wydziatu V WUBP w Krakowie za miesiac wrzesień 1951 roku do naczelnika Wydziatu V Departamentu MBP w Warszawie, Kraków, 6 X 1951 r. (ściśle tajne), s. 171.

${ }^{27}$ Por. tamże, Sprawozdanie z pracy Sekcji V Wydziału V WUBP w Krakowie za miesiac czerwiec 1952 roku do naczelnika Wydziatu V Departamentu MBP w Warszawie, Kraków, 10 VII 1952 r. (ściśle tajne), s. 274. 
-misyjna) jezuitów, salwatorianów, bernardynów, misjonarzy, kapucynów i karmelitów bosych oraz pijarów ${ }^{28}$.

Przez werbunek informatorów ze środowiska zakonnego, badanie nastrojów w klasztorach oraz gromadzenie materiałów o karmelitach bosych a zwłaszcza analiza ich wypowiedzi miała dla referentów UB zasadnicze znaczenie. Po pierwsze znali opinie karmelitów co do polityki władz państwowych i partyjnych oraz mogli gromadzić ,kompromitujące materiały”. Dzięki nim mogli szantażować niektórych zakonników i zmuszać do współpracy, mogli na ich podstawie niektórych oskarżać a także mogli weryfikować prawdziwość wypowiedzi innych tajnych współpracowników.

W marcu 1953 roku chor. Władysław Pierścionek z WUBP w Krakowie w sprawozdaniu do naczelnika Wydziału II Departamentu XI Ministerstwa Bezpieczeństwa Publicznego pisal: Przelożony klasztoru oo. Karmelitów B. w Wadowicach Prus Jan na temat rozwiqzania KSMM $i$ ZRD powiedzial, że nie powinni rozwiazywać tych organizacji w całości, a rozwiazać tylko tych, którzy przyczynili się do zdrady narodowej $i$ wspótpracowali ze szpiegiem Chachlica. Następnie tenze Prus jak podaje dalej $k$ [ontakt] $p$ [oufny] na temat Dekretu powiedziat, ze władze kościelne sa tym skrępowane, że same nie będq mogły obsadzać stanowisk kościelnych, ale z drugiej zaśs strony powiedzial, że kiedy same wladze kościelne obsadzity kurię krakowską księżmi to znaleźli się i tam szpiedzy, o których nawet arcybiskup Baziak i biskup Rospond wiedzieli, gdyz informowat ich o tym ksiadz Lelito. Na zakończenie tej dyskusji Prus powiedziat, że dekret na przyszlość chroni autorytet władzy kościelnej wobec narodu polskiego. Na temat zjazdu księzy w Wadowicach $w$ dniu 12.2 .53 oświadczyt, że nie mógt być na tym zjeździe ponieważ byl zaproszony do kurii krakowskiej do biskupa Jopa, ale on catkiem popiera cel zjazdu $u^{29}$.

Władze bezpieczeństwa na wszelkie sposoby inwigilowały środowiska zakonne. Należy dodać, że nie chodziło tylko o pozyskiwanie informacji o działalności zakonników, ale o zwalczanie Kościoła katolickiego jako instytucji wrogiej dla państwa kierującego się ideologia komunistyczna. W tym celu wykorzystywano sieć informatorów (tajnych współpracowników), donosicieli, anonimy oraz informacje od tzw. pomocy obywatelskich. W początkach lat pięćdziesiątych Wojewódzki Urząd Bezpieczeństwa Publicznego pod kryptonimem „Wstrzemięźliwi” prowadził intensywną penetrację klasztorów oraz inwigilował zakonników. W jednym z zachowanych sprawozdań znajduje się informacja, że $w$ dniu 10 marca 1953 r. Kowalewski Hipolit - Cyryl karmelita bosy w Czernej będac w Krzeszowicach u dentysty w poczekalni wypowiedziat się z ironiq wobec ludności na temat zgonu tow. J. Stalina, ze tow. Stalin nie zmarl, a tylko poszedl na konferencje do

${ }^{28}$ Por. tamże, t. 3, Sprawozdanie p.o. kierownika ppor. Z. Faryny z pracy Sekcji II $W y$ dziatu XI WUBP w Krakowie za okres 1 -3I III 1953 roku do naczelnika Wydziatu II Departamentu XI MBP w Warszawie, Kraków, 3 IV 1953 r. (ściśle tajne), s. 19; tamże, t. 4, Sprawozdanie kpt. Z. Glińskiego naczelnika Wydzialu XI WUBP w Krakowie za miesiqc marzec 1953 roku do Dyrektora Departamentu XI MBP w Warszawie, Kraków, 11 III 1953 r. (ściśle tajne), s. 26.

${ }^{29}$ Tamże, t. 3, Kler zakonny męski. Obiekty po linii Sekcji III Wydziału II Departamentu XI MBP za okres l-28 II 1953 roku [Sprawozdanie prowadzącego chor. W. Pierścionka do naczelnika Wydziału II Departamentu XI MBP w Warszawie], Kraków, 4 III 1953 r. (ściśle tajne), s. 9. 
Lenina. W zwiqzku z powyzszym przestuchanych zostalo 2-ch świadków, którzy potwierdzili te wypowiedzi $i^{30}$.

Oprócz rozpoznawania środowiska bardzo często wobec osób zakonnych prowadzono przesłuchania, zatrzymania, aresztowania, dochodzenia sądowe lub orzekano kary za najmniejsze nawet wykroczenia. Niekiedy posługiwano się prowokacja. Powszechnym były wówczas kontrole kazań. Ofiarą takiej „,polityki” UB byli także karmelici bosi. W sprawozdaniı w maju 1953 roku Z. Faryna donosił do Warszawy: $w$ dniu $6 \mathrm{~V} 1953 \mathrm{r}$. dokonaliśmy aresztowania o. Kupnego Pawla "Hermana" s. Piotra i Marii Jeziorskiej, ur. 2 XI 1921 w Maciejkowicach woj. Stalingród, ostatnio zamieszkałego w Klasztorze OO. Karmelitów Bosych w Czernej, pow. Chrzanów. Aresztowanego w tym samym dniu przekazaliśmy do WUBP w Stalinogradzie, którzy prowadzi p-ko wym. sprawę o wrogie wystapienia na kazaniach na terenie woj. stalinogrodzkiego ${ }^{31}$.

Służby bezpieczeństwa interesowały się nie tylko nastrojami pomiędzy zakonnikami i treścią kazań. Odnotowywano wszelką aktywność. W sprawozdaniu za miesiąc październik 1953 roku chor. Marian Mercik donosil do Ministerstwa Bezpieczeństwa Publicznego o próbach osiedlenia się karmelitów bosych w Kluszkowcach: na terenie gminy Czorsztyn pow. Nowy Targ w gromadzie Kluszkowce ok. 2 m-ce temu osiedlito się dwóch zakonników OO. Karmelitów Bosych a to o. Filek Jakub i o. Król Stanistaw. Zamieszkali oni w domu, w którym mieści się kaplica publiczna, poprzednio obstugiwana przez wikariusza parafii Maniowy oddalonej od Kluszkowic w najdalszym punkcie o $7 \mathrm{~km}$. Wyzej wspomnieni przyjechali tam rzekomo na odpoczynek. Tymczasem $w$ ostatnich dniach zameldowali sie na pobyt stały. Miejscowa ludność na wlasny koszt wyremontowata im dwa pokoje, w których zamieszkali i zaczęli się [!] spetnianiem obowiazków kaplańskich bez zezwolenia Prezydium WRN na wykonywanie tych obowiqzków. Ponieważ pobyt ich przedluzal się Pr. PRN wezwalo o. Filka celem wyjaśnienia tej sprawy. Po powrocie z tej rozmowy o. Filek wspólnie z o. Królem wptynęli na miejscowa ludność w ten sposób, że ludnosśc ta wniosta do Pr. PRN w Nowym Targu petycje podpisana przez ok. 300 osób z prośba o pozostawienie wspomnianych wyżej na dotychczasowym stanowisku. W międzyczasie uzyskaliśmy dane, że księża ci zamierzaja stworzyć tam nowa placówkę parafialnq. W zwiazku $z$ tym, jak równiez biorac pod uwage fakt, że w/w sa zdecydowanie wrogo nastawieni do obecnej rzeczywistości, postanowiliśmy przez władze administracyjne usunać ich z tego terenu.

${ }^{30}$ Tamże, Charakterystyka obiektu „Wstrzemięźliwi” - kler zakonny męski za okres I-3I III 1953 roku, Kraków, IV 1953 r. (ściśle tajne), s. 31

${ }^{31}$ Tamże, Sprawozdanie p.o. kierownika ppor. Z. Faryny z pracy Sekcji II Wydzialu XI WUBP $w$ Krakowie za okres 1-30 V 1953 roku do naczelnika Wydziału II Departamentu XI MBP w Warszawie, Kraków, 26 V 1953 r. (ściśle tajne), s. 63-64. Toż: tamże, t. 4, Sprawozdanie kpt. Z. Glińskiego naczelnika Wydzialu XI WUBP w Krakowie za miesiqc marzec 1953 roku do dyrektora Departamentu XI MBP w Warszawie, Kraków, 1953 r. (ściśle tajne), s. 51-52. O. Herman został skazany na 9 miesięcy ograniczenia wolności. Szerzej na ten temat zob. J. Wanat, Kupny Pawel Karol, [w:] Leksykon duchowienstwa represjonowanego w PRL w latach 1945-1989, t. 2, red. J. Myszor, Warszawa 2003, s. 147-149.

${ }^{32}$ IPNKr, sygn. 039/1, t. 3, Sprawozdanie p.o. kierownika chor. M. Mercika z pracy Sekcji II Wydzialu XI WUBP w Krakowie za okres 1-31 X 1953 roku do naczelnika Wydziatu II Departamentu XI MBP w Warszawie, Kraków, 4 XI 1953 r. (ściśle tajne). Zatacznik, s. 143. 
W 1954 roku uaktywnił się informator o pseudonimie „Zborowski”. Pozostawał on na kontakcie $z$ chor. Ludwikiem Kucielem. Jak wynika z zachowanych sprawozdań szefów WUBP w Krakowie przekazywal referentom UB informacje o nastrojach w klasztorach i wśród duchowieństwa diecezjalnego, o prowadzonych dyskusjach na tematy polityczne oraz o wewnętrznych sprawach karmelitów bosych. W lutym 1954 roku „Zborowski” informowal, że między karmelitami bosymi konferencja w Berlinie wywołała „dość ożywioną dyskusję". Nie wahał się donosić, iż szczególny głos w tych dyskusjach zabierał o. Hieronim Pszczółka i o. Apoloniusz Godynia ${ }^{33}$.

W marcu 1954 roku kierownik Sekcji II Wydziału XI WUBP w Krakowie opierając się najprawdopodobniej na informacjach „Zborowskiego" relacjonował do Warszawy: $1 / W$ zwiqzku z przeniesieniem z Poznania do Lublina o. Eliasza, wśród księży z tego klasztoru panuje duze oburzenie na przelożonych za to pociqgniecie. Szczególnie daje się to zauwazyć $w$ klasztorach $w$ Wadowicach i $w$ Czernej. Księza w rozmowach na ten temat mówia że przełożeni postapili niewłaściwie przenoszac o. Eliasza za to, ze uzyskat z Kurii w Poznaniu zezwolenie na czytanie przez kleryków ksiqżek znajdujących się na indeksie. Księża twierdza że myśl przeniesienia 0 . Eliasza podat $X$. prowincjalowi pierwszy definitor $O$. Bazyli, który przebywa $w$ klasztorze krakowskim. W wypowiedziach swoich księza daja wyraźnie do zrozumienia, iż solidaryzuja się ze stanowiskiem o. Eliasza.

2/ Również wśród księzy z tego klasztoru II-gi zjazd wywolal szeroki oddźwięk. Księża $z$ iego klasztoru w rozmowach pomiędzy soba szeroko komentowali przebieg II Zjazdu, oraz poszczególne referaty. Doszli oni do przekonania, że za mało jest czytać przebieg zjazdu i poszczególne referaty oraz dyskusje nad nimi, lecz cały ten material należy „studiowac" jak sie wyraził O. Paulin. Duże wrazenie zrobil na nich referat tow. Bieruta [...] W rozmowach na temat przebiegu II-go Zjazdu poszczególni ojcowie Jak: o. przeor, o. Emil, o. Paulin, o. Michat, o. Apoloniusz podkreślali, ze $z$ referatów wygłoszonych na Zjeździe oraz z dyskusji przebiega szczerość, widać wśród spoleczeństwa chęć do ofiarnej pracy dla wspólnego dobra" ${ }^{34}$.

Wiadomości te - z uwagi na ich szczególne znaczenie -- przekazal także sam naczelnik Wydziału XI WUBP w Krakowie kpt. Zygmunt Gliński na ręce dyrektora Departamentu XI MBP ${ }^{35}$.

W marcu 1953 roku, mimo, że agentura UB posiadała w środowisku karmelitów bosych tajnych współpracowników, to jednak rozpoczęto opracowywanie kandydata na werbunek o kryptonimie „Organista”. Byla to osoba świecka, która posiadała bardzo bliski kontakt z karmelitami bosymi z klasztoru krakowskiego. Opiekę nad nim zlecono chor. Ludwikowi Kucielowi, doświadczonemu funkcjo-

${ }^{33}$ Por. tamże, t. 7, Ocena pracy Sekcji II Wydziahu VI za rok 1955 i zadania na najbliższy okres, Kraków, 2 III 1956 r. (ściśle tajne), s. 159; IPNKr, sygn. 039/1, t. 3, Sprawozdanie kierownika ppor. Z. Faryny z pracy Sekcji II Wydzialu XI WUBP w Krakowie za okres I-28 II I954 roku do naczelnika Wydziatu II Departamentu XI MBP w Warszawie, Kraków, 1 III 1954 r. (ściśle tajne). Zatacznik, s. 200; J. M a r e c k i, Wykaz wspótpracowników..., s. 16.

${ }^{34}$ Tamże, Sprawozdanie kierownika ppor. Z. Faryny z pracy Sekcji II Wydziatu XI WUBP w Krakowie za okres 1-31 III 1954 roku do naczelnika Wydziatu II Departamentu XI MBP w Warszawie, Kraków, 31 III 1954 r. (ściśle tajne). Załącznik, s. 221.

${ }^{35}$ Por. tamże, t. 4, Sprawozdanie kpt. Z. Glińskiego naczelnika Wydzialu XI WUBP w Krakowie za miesiac marzec 1954 roku do dyrektora Departamentu XI MBP w Warszawie, Kraków, 7 IV 1954 r. (ściśle tajne), s. 228. 
nariuszowi, który nadzorował wszelkie działania nad karmelitami bosymi w województwie krakowskim ${ }^{36}$.

W kwietniu 1954 roku „Zborowski” donosił do UB o wyborze delegatów na kapitułę prowincjalną (8-10 V 1954), którą funkcjonariusz UB relacjonujący o niej swoim zwierzchnikom w Warszawie nazwał generalną. „Zborowski” podal, że największe szanse wyboru miał o. Bazyli Jabłoński ale też typował o. Walerego Rynka i o. Augustyna Kozłowskiego. W miesiąc później doniósł o odbytej kapitule prowincjalnej, wyborze o. Józefa Prusa na stanowisko prowincjała, wyborze definitorów i przeorów poszczególnych klasztorów oraz proboszczów parafii ${ }^{37}$.

Wspomniany informator „Zborowski” pracował dla służb bezpieczeństwa nie tylko w środowisku karmelitańskim. Latem 1954 roku miał informować o nastrojach w środowiskach zakonnych co do przesiedlenia bernardynów z Alwernii do Kalwarii Zebrzydowskiej ${ }^{38}$.

Intensyfikacja donosicielstwa „Zborowskiego” nasiliła się wraz z okresowym przyjazdem br. Franciszka Woźniaka z Rzymu do Polski w celu odwiedziny krewnych. W kraju miał pozostawać około dwa miesiące. Dla służb bezpieczeństwa pobyt br. Franciszka w Polsce i jego ewentualna działalność szpiegowska była tak ważna, że do precyzyjnego rozpracowania i kontrolowania zaangażowano ponadto, obok "Zborowskiego", tajnego wspólpracownika UB o pseudonimie „Żagielewski”, który będąc osobą duchowną na wysokim stanowisku miał możliwość wniknięcia do środowiska karmelitów bosych. Niestety, ani „Zborowskiemu" ani „Żagielewskiemu" nie udało się ustalić rzeczywistego powodu pobytu br. Franciszka w Polsce ani też dowiedzieć, z kim się kontaktował, czy przekazywał albo otrzymywał listy lub przesyłki ${ }^{39}$.

W październiku 1954 roku „Zborowski” przebywał na urlopie zdrowotnym. Jak wynika z raportów nad karmelitami bosymi „czuwał” wspomniany „Zagielowski”,40.

${ }^{36}$ Por. tamże, Sprawozdanie kpt. Publicznego. Glinskiego naczelnika Wydzialu XI WUBP w Krakowie za miesiac marzec 1953 roku do dyrektora Departamentu XI MBP $w$ Warszawie, Kraków, 11 III 1953 r. (ściśle tajne), s. 19; Tamże, t. 7, Ocena pracy Sekcji II Wydzialu VI za rok 1955 i zadania na najbliższy okres, Kraków, 2 III 1956 r. (ściśle tajne), s. 159; J. M a r e c k i, Wykaz wspótpracowników..., s. 123.

${ }^{37}$ Por. IPNKr, sygn. 039/1, t. 3, Sprawozdanie kierownika ppor. Z. Faryny z pracy Sekcji II Wydziaiu XI WUBP w Krakowie za okres 1-30 IV 1954 roku do naczelnika Wydziatu II Departamentu XI MBP w Warszawie, Kraków, 3 V 1954 r. (ściśle tajne). Charakterystyczne fakty i zmiany w poszczególnych obiektach i środowiskach, Kraków, I VI 1954 r., s. 231-232, 247; Tamże, t. 4, Sprawozdanie kpt. Z. Glińskiego naczelnika Wydzialu XI WUBP w Krakowie za miesiqc kwiecien 1954 roku do dyrektora Departamentu XI MBP w Warszawie, Kraków, 1953 r. (ściśle tajne), s. 251-252.

${ }^{38}$ Por. tamże, t. 3, Przesiedlenie zakonów. 1954, Pismo kpt. S. Florka z-cy naczelnika Wydziatu XI-go. Plan przedsięwzięć w zwiazku z akcja przesiedlenia zakonników OO. Bernardynów z klasztoru w Alwernii do klasztoru w Kalwarii, Kraków, 23 VII 1954, s. 141-143.

${ }^{39}$ Por. tamże, Sprawozdanie kierownika ppor. Z. Faryny z pracy Sekcji II Wydzialu XI WUBP w Krakowie za okres 1-31 VII 1954 roku do naczelnika Wydziatu II Departamentu XI MBP w Warszawie, Kraków, 4 VIII 1954 r. (ściśle tajne). Charakterystyczne fakty i zmiany w poszczególnych obiektach i środowiskach, Kraków, 1954 r., s. 285. Toż: tamże, t. 4, Sprawozdanie kpt. Z. Florka naczelnika Wydzialu XI WUBP w Krakowie za miesiac lipiec 1954 roku do dyrektora Departamentu XI MBP w Warszawie, Kraków, 6 VIII 1954 r. (ściśle tajne), s. 317.

${ }^{40}$ Por. tamże, t. 3, Sprawozdanie kierownika por. Z. Faryny z pracy Sekcji II Wydzialu XI WUBP w Krakowie za okres 1-31 X 1954 roku do naczelnika Wydziatu II Departamentu XI $M B P$ w Warszawie, Kraków, 3 XI 1954 r. (ściśle tajne), s. 328. 
Donosił wówczas, że nie notuje się wrogich wystapień karmelitów bosych. Dodawał jednak, że pod pozorem pomocy duszpasterskiej wyjeżdżają w terenie aby docierać do środowisk wiejskich. Z jego informacji UB dowiedziało się także, że 21 listopada t. r. w kościele karmelitów bosych (prawdopodobnie w Krakowie) miało odbyć się uroczyste nabożeństwo $\mathrm{z}$ udziałem wielu prowincjałów i przełożonych klasztorów $z$ całego województwa $z$ okazji jubileuszu maryjnego. Zgromadzeni na modlitwie mieli ponadto złożyć ślubowanie wierności papieżowi ${ }^{41}$.

W listopadzie, po miesięcznym urlopie zdrowotnym, powrócił do klasztoru konfident „Zborowski”. Jako pierwszą informację podal, ze 21 XI w kościele karmelitów bosych odbyla się uroczystość ofiarowania się rodzin zakonnych męskich Matce Bozej z okazji roku maryjnego ${ }^{42}$.

Pod koniec roku 1954 aktywność „Zborowskiego” znacznie zmalała. W jednym ze sprawozdań por. Zbigniewa Faryny do jego władz w Ministerstwie Bezpieczeństwa Publicznego w Warszawie widnieje adnotacja, że na polecenie władz zakonnych informator „Zborowski” wyjeżdżał z klasztoru i w miesiącu grudniu odbyto z nim tylko jedno spotkanie ${ }^{43}$. W jesieni 1955 roku zastapił go inny informator, gdyż - jak zaznaczono w sprawozdaniu za trzeci kwartał tego roku - „Zborowski" był niechętny do dalszej wspólpracy. We wrześniu dokonano werbunku inf. ps. "Stopa" do rozpracowania zakonu OO Karmelitów Bosych - klasztor w Krakowie. Inf. „Stopa” jest osoba cywilnq, posiada wyższe wyksztatcenie. Jest od szeregu lat zatrudniony w tym klasztorze. Wymieniony opracowywany byt pod kryptonimem ,, Organista, ${ }^{, 44}$.

Nie zerwano jednak kontaktu ze „Zborowskim”. Jeszcze w marcu 1956 roku był wymieniany jako pozostający na kontakcie $\mathrm{z}$ oficerem UB Ludwikiem Kucielem. Kilka miesięcy później, w rocznym sprawozdaniu sporządzonym w dniu 6 października 1956 roku, podano tylko lakonicznie, że informator noszący pseudonim ,Zborowski" został zdekonspirowany ${ }^{45}$.

${ }^{41}$ Por. tamże, s. 336-337; tamże, t. 4, Sprawozdanie kpt. Z. Florka naczelnika Wydzialu XI WUBP w Krakowie za miesiqc pażdziernik 1954 roku do dyrektora Departamentu XI MBP w Warszawie, Kraków, 6 XI 1954 r. (ściśle tajne), s. 376-377.

${ }_{42}$ Tamże, t. 3, Sprawozdanie kierownika por. Z. Faryny z pracy Sekcji II Wydzialu XI WUBP w Krakowie za okres 1-30 XI 1954 roku do naczelnika Wydziatu II Departamentu XI $M B P w$ Warszawie, Kraków, 30 XI 1954 r. (ściśle tajne). Charakterystyczne fakty i zmiany w poszczególnych obiektach i środowiskach, 30 XI 1954 r., s. 359.

${ }^{43}$ Por. tamże, Sprawozdanie kierownika por. Z.Faryny z pracy Sekcji II Wydziahu XI WUBP w Krakowie za okres 1-31 XII 1954 roku do naczelnika Wydzialu II Departamentu XI MRP w Warszawie, Krakśw, 3 I 1955 r. (ściśle tajne), s. 370; Też: tamże, Ł. A, Sprawozdanic kpt. Z. Florka naczelnika Wydziału XI WUBP w Krakowie za miesiac grudzień 1954 roku do dyrektora Departamentu XI MBP w Warszawie, Kraków, 8 I 1955 r. (ściśle tajne), s. 406.

${ }_{44}^{44}$ Tamże, t. 7, Sprawozdanie kierownika Sekcji II Wydziatu VI por. Z. Faryny z pracy Sekcji II Wydziahu VI WU ds. BP w Krakowie za okres od dnia 1 VII 1955 do dnia 30 IX 1955 do naczelnika Wydziału II Departamentu VI Komitetu ds. Bezpieczeństwa Publicznego w Warszawie, Kraków, 1 X 1955 r. (ściśle tajne), s. 70; Toż: tamże, Ocena pracy Sekcji II Wydziahu VI za rok 1955 i zadania na najbliższy okres, Kraków, 2 III 1956 r. (ściśle tajne), s. 263; J. M a r e c k i, Wykaz wspótpracowników..., s. 25.

${ }^{45}$ Por. IPNKr, sygn. 039/1, t. 7, Ocena pracy Sekcji II..., s. 159; tamże, t. 8, Sprawozdanie z pracy Wydziatu VI WUdSBP w Krakowie za okres od września 1955 raku do 30 września 1956 roku, Kraków, 6 X 1956 r. (ściśle tajne), s. 162. 
„Stopa" - nowy konfident, przynajmniej początkowo, godnie zastapił „Zborowskiego". Jak wynika $z$ doniesień znał dobrze krakowskie środowisko karmelitańskie. Kierownik Sekcji II Wydziału VI krakowskiego WUBP por. Zbigniew Faryna w kwartalnym sprawozdaniu do swych zwierzchników pisał, że nowo zwerbowany inf. „Stopa” w omawianym okresie podal, iż br. Walenty Antoni Marszalik, który okresowo, przez dwa miesiące, przebywa w Polsce jest z pochodzenia Polakiem, do kurii generalnej Zakonu wyjechał przed wojną i pracuje tam $\mathrm{z}$ innym Polakiem. Na potwierdzenie tego Faryna powoływał się na bliżej nieznane relacje z przesłuchania o. Majty, który miał stwierdzić, że br. Walenty chętnie wróciłby do Polski, do jednego z klasztorów karmelitańskich, ale „Rada Generalna nie chce ich podobno puścić". Ponadto „Stopa" donosił, że prowincjał mimo, iz ma siedzibę w Warszawie to przebywa w Wadowicach, bo w Warszawie nie może otrzymać zameldowania. Poinformował także UB, że na misjach $w$ Indiach spośród karmelitów przebywa o. Putek ${ }^{46}$. Wydaje się, że informacje te nie miały większej wartości operacyjnej.

W jesieni 1955 roku konfident „Stopa” donosil, że z klasztoru OO Karmelitów Bosych chce wystapić br. $W[\ldots]$, który z życia zakonnego nie jest zadowolony. Niejednokrotnie mówit, że odejdzie z klasztoru, ale nie wie czy z tego powodu, że był w klasztorze wladze świeckie nie będq mu robić trudności w dostaniu pracy. $Z$ wym. będzie przeprowadzona rozmowa orientacyjna ${ }^{47}$.

W 1955 roku karmelici bosi na terenie ówczesnego województwa krakowskiego byli pod szczególną kontrolą służby bezpieczeństwa. Skrupulatnie odnotowywano takie fakty jak prowadzenie katechezy przyklasztornej oraz, że nie zgłosili prowadzonych przez siebie rekolekcji, w zwiazku z czym Referat do Spraw Wyznań Prezydium WRN zabronił im dalszego ich prowadzenia. Należy wyjaśnić, że rekolekcje mogli głosić tylko ci księża, którzy ślubowali lojalność władzom PRL ${ }^{48}$. W kwietniu 1956 roku w jednym ze sprawozdań Wojewódzkiego Urzędu do Spraw Bezpieczeństwa Publicznego w Krakowie odnotowano: $z$ dokumentu , W" [dozór korespondencji] uzyskanego na zakon Karmelitów Bosych wynika, że brat zakonny Kasjan od Matki Bożej pisze do ob. w Zielonej Górze ZS Deserowie co nastepuje: Rozumiem twoje oburzenie na ustawe o przerywaniu ciaży. Nie mogłem sie nadziwić, ze Hitler zmierzajac do zbrodniczych swych planów okazat się w tym względzie o wiele więcej przewidujacym niż nasi nowie posłowie,

${ }^{46}$ Por. tamże, t. 7, Sprawozdanie kierownika Sekcji II..., Kraków, 1 X 1955 r. (ściśle tajne), s. 85-86; Toż: tamże, t. 8, Sprawozdanie z pracy Wydziału VI WUdSBP w Krakowie za III kwartal 1955 roku do dyrektora Departamentu VI Komitetu do Spraw Bezpieczeństwa Publicznego w Warszawie, Kraków, 5 X 1955 r. (ściśle tajne), s. 98.

${ }^{47}$ Tamże, t. 7, Sprawozdanie kierownika Sekcji II Wydzialu VI por. Z. Faryny z pracy Sekcji II Wydziatu VI WUdS BP w Krakowie za okres od dnia 1 X 1955 do dnia 30 XII 1955 roku do naczelnika Wydziału II Departamentu VI Komitetu do Spraw Bezpieczeństwa Publicznego w Warszawie, Kraków, 4 I 1956 r. (ściśle tajne). Załacznik, s. 104; Toż: tamże, t. 8, Sprawozdanie z pracy Wydzialu VI WUdSBP w Krakowie za IV kwartat 1955 roku do dyrektora Departamentu VJ Komitetu do Spraw Bezpieczeństwa Publicznego w Warszawie, Kraków, 30 XII 1955 r. (ściśle tajne), s. 129.

${ }^{48}$ Por. tamże, t. 7, Ocena pracy Sekcji II..., Kraków, 2 III 1956 r. (ściśle tajne), s. 150; tamże, Sprawozdanie z pracy Sekcji II Wydziatu VI WUdSBP w Krakowie za okres od dnia II 1956 do dnia 28 III 1956 roku do naczelnika Wydziału II Departamentu VI Komitetu do Spraw Bezpieczeństwa Publicznego w Warszawie, Kraków, 25 III 1956 r. (ściśle tajne), s. 163. 
których obowiqzkiem ma być przeciez dbatość o sit naszego narodu. Uchwalili oni natomiast uchwalę, której najprostszym wynikiem będzie zdegenerowanie naszego narodu. Niszczenie tych wartościowych ludzi wydaje im sie koniecznym by swobodnie mogli żyć ich mordercy. Myślę, że uchwalenie tej ustawy powinno wywołać zdrowa reakcję wśród katolików. Reakcja nie buntu, ale reakcja porzqdnego życia. To rozporzqdzenie powinno wywołać zbawienny odruch przeciwstawienia się właśnie tej podlości. Teraz zamiast zwiększania się tego zabiegu powinien być zmniejszony do minimum lub coby dat Bóg usunięty zupetnie z życia katolików. Jestem przekonany, że tak będzie u dobrych katolików ale jak wielkq pokusę będzie stanowita ta ustawa dla stabych lub ztych. Istnieje na ten temat powiedzenie, ze katolicy nie będa tego robili, ale komuniści staraja sie robić co tylko moga by sie jak najprędzej wyniszczyć. W klasztorze tym zostat wytypowany i opracowany kandydat na werbunek D. J. wywodzacy się $z$ aktywu zakonnego ${ }^{49}$. Nie udało się ustalić czy D. J. został współpracownikiem Służby Bezpieczeństwa.

W 1957 roku Grupa V krakowskiego Urzędu do Spraw Bezpieczeństwa Publicznego ponownie przyjęła „na kontakt” informatora o pseudonimie „Satyr” karmelite bosego od ministerialnego pracownika Departamentu III. Jest to jednostka cenna - sprawdzona. Dotqd nie zostal zarejestrowany, ponieważ jeszcze nie nadeszly teczki ${ }^{50}$. Wcześniej przebywal on już na terenie województwa krakowskiego.

W 1957 roku i w latach następnych, mimo początkowych zmian społecznopolitycznych, służby bezpieczeństwa nadal pracowały bardzo aktywnie. Dnia 27 listopada 1957 roku została założona sprawa agenturalnego sprawdzenia kryptonim „Nieznany” (nr 829/E) na przeora klasztoru krakowskiego o. Mariana Romana Wojnicza. Materiał pozyskany ze źródła „Satyr” wskazywał, że Wojnicz ukrywa się pod fałszywym nazwiskiem gdyż obawiał się odpowiedzialności za swoja działalność przeciw ZSRR na terenach wschodnich podczas okupacji. „Satyr” podawał, że Wojnicz wstapił do klasztoru w 1948 roku jako czlowiek dorosły. Donosił także - opierając się na obserwacjach jednego z zakonników - że Wojnicz jako kleryk obawiał się spotkania $z$ pewnym prałatem $w$ Warszawie. Tenże prałat miał do niego później powiedzieć: „uspokoiłeś się już -- nie bój się”. Wojnicz miał też przechwalać się, że umie podrabiać pieniądze oraz nie ukrywał swej nienawiści do ZSRR. Na podstawie powyższych informacji Grupa V zajęła się ustalaniem nazwiska prałata z Warszawy oraz zwróciła się pisemnie do Dyrektora Gabinetu Ministra o spowodowanie przeprowadzenia ustalen za Wojniczem na terenie wileńszczyzny, ponieważ z akt BDO można mieć poważne watpliwości co do treści podanych przez niego danych przy wyrabianiu dowodu osobistego ${ }^{51}$.

${ }^{49}$ Tamże, Sprawozdanie kwartalne z pracy Sekcji II Wydzialu VI WUdSBP w Krakowie za okres od dnia IIV do dnia 28 VI 1956 roku do naczelnika Wydzialu II Departamentu VI Komitetu do Spraw Bezpieczeństwa Publicznego w Warszawie, Kraków, 28 VI 1956 r. (ściśle tajne), s. $208-209$.

${ }^{50}$ Por. tamże, t. 9, Sprawozdanie z pracy Grupy Vi Va Wydziatu III KWMO w Krakowie za IV-ty kwartal 1957 roku do naczelnika Wydziału V Departamentu III MSW $w$ Warszawie, Kraków, 29 XII 1957 r. (ściśle tajne), s. 46; J. M a r e c k i, Wykaz wspótpracowników..., s. 14.

${ }^{51}$ Tamże, t. 9, Sprawozdanie z pracy Grupy V $i$ Va Wydzialu III KWMO w Krakowie za IV-ty kwartat 1957 roku do naczelnika Wydzialu V Departamentu III MSW w Warszawie, Kraków, 29 XII 1957 r. (ściśle tajne), s. 45. 
„Satyr” informował, że o. Wojnicz często wychodzi z klasztoru, lecz nie udało mu się ustalić w jakim celu i z kim się spotyka. Zbierał także o nim wypowiedzi innych zakonników, $\mathrm{m}$. in. to, że jeden karmelita z Poznania miał powiedzieć o o. Wojniczu ,że nie trzeba się mu dziwić, iż jest gburowaty i dziwnie się zachowuje, ponieważ miał w życiu wiele przykrości, byl ścigany, sądzony i skazany". Sprawozdawca nadmienił, że do czasu otrzymania odpowiedzi od Organów Bezpieczeństwa Publicznego ZSRR nie będzie się stosować innych przedsięwzięć jak tylko obserwacja ${ }^{52}$.

W 1958 roku krakowskie służby bezpieczeństwa nadal pracowały nad o. Wojniczem. Wszelkie działania określano kryptonimem „Nieznany”. W styczniu tego roku dokonano spośród karmelitów bosych werbunku informatora o pseudonimie „Sikorski” do sprawy o kryptonimie „Nieznany". Podczas werbunku jak i na nastepnych spotkaniach $w$ duzym stopniu potwierdzil posiadane w sprawie materiaty ze źródla ,, Satyr". Werbunek należy ocenić jako celowy $i$ z perspektywa ${ }^{53}$.

"Satyr" donosił także do władz bezpieczeństwa o takich wydarzeniach jak spotkania prowincjałów czy rektorów wszystkich polskich seminariów zakonnych. W jednym ze sprawozdań odnotowano, że „Satyr” poinformował władze o opracowanym planie pracy duszpasterskiej wśród ministrantów, który zaaprobował prymas Stefan Wyszyński. Był to trzymany w tajemnicy plan. Wiedziało o nim tylko pięciu kapłanów, którymi kierował ks. Małysiak ${ }^{54}$. Tajny współpracownik „Satyr" był więc cennym dla służb bezpieczeństwa informatorem, posiadającym interesujące kontakty z krakowskim środowiskiem kościelnym.

Wszyscy wymienieni współpracownicy byli zaangażowani do rozpracowania krakowskiego przeora karmelitów bosych. W marcowym sprawozdaniu w 1958 roku skierowanym z Krakowa do naczelnika Wydziału V Departamentu III Ministerstwa Spraw Wewnętrznych znaczną jego część zajmuje omówienie sprawa agenturalnego sprawdzenia obiektu o kryptonimie „Nieznany”: w okresie sprawozdawczym do sprawy pozyskano szereg nowych materiatów zarówno od tkwiacego w sprawie inf. ps. "Satyr" jak też od zwerbowanego w styczniu inf. ps. „Sikorski”. Inf. PS. ", Sikorski" przy werbunku jak tez i na nastęnych spotkaniach potwierdzit $w$ zasadzie nasze poprzednie materiaty $w$ sprawie podejrzen, że figurant [Wojnicz] użwa cudzego nazwiska a ponadto że jest zdecydowanym wrogiem Polski Ludowej i ZSRR. Inf. ps. „Satyr" podat, ze na kazaniu 15 stycznia br. figurant prowadzit wrogq agitacje polityczna. $M$. in. wyrazit sie on tak: „Pracujesz jak świnia i co ci za to ojczyzna da, co ci da Partia?". Dalej wypowiadat sie ze władze znowu naciskaja kościól, zakony i gdzie w takim stanie rzeczy mozna mówić o tym, że po „październiku” jest dobrze $e^{55}$. W dalszej części sprawozdania jest mowa o tym, że Wojnicz agitował kleryków aby nie brali udziału w głosowaniach.

${ }^{52}$ Por. tamże, s. 45-46.

${ }^{53}$ Tamże, Sprawozdanie z pracy operacyjnej Grup V i Va Wydzialu III KWMO w Krakowie za okres I kwartatu 1958 roku do naczelnika Wydziatu V Departamentu III MSW W Warszawie, Kraków, 29 III 1958 r. (ściśle tajne), s. 106.

${ }^{54}$ Por. tamże, s. 115; Tamże, Sprawozdanie z pracy Grup V $i$ Va Wydzialu III KWMO w Krakowie za okres III-go kwartatu 1958 roku do naczelnika Wydzialu V Departamentu III MSW w Warszawie, Kraków, 24 IX 1958 r. (ściśle tajne), s. 207.

${ }^{55}$ Tamże, Sprawozdanie z pracy operacyjnej Grup V..., Kraków, 29 III 1958 r. (ściśle tajne), s. 98 . 
W miesiąc później donoszono do Warszawy: Zgodnie z instrukcjq przedłużono termin rozpracowania, z uwagi na to, ze dotad nie wyjaśniono sprawy. $W$ szczególności dotad nie otrzymano odpowiedzi od organów bezpieczeństwa ZSRR. W okresie sprawozdawczym uzyskano dane z Wydzialu III SB we Wroctawiu, że figurant utrzymuje kontakty z b. członkami $A K$ z okręgu wileńskiego. Bezspornie stwierdzono, że jest on w kontakcie $z$ b. czlonkiem sztabu okręgu wileńskiego AK Kielka Stanisławem zam. we Wroclawiu ul. Ruska 13/1, który po wyzwoleniu byt aresztowany i przebywat w Zw. Radzieckim do 1956 r. Kielka jak wynika z posiadanych materiatów, nawiqzuje kontakty z innymi czt. AK okregu wilenskiego, nie tylko $w$ kraju, ale $i$ za granica. $W$ tej sprawie uzgodniono $z$ Wydzialem III-cim we Wroclawiu wspólne działanie. Dodatkowo zaplanowano i poczyniono już kroki w kierunku wykorzystania do sprawy sieci spośród czlonków AK okregu wileńskiego z terenu kraju. Uczyniono to dlatego, ze bezspornym wydaje sie fakt działalności figuranta w AK na terenie wileńszczyzny. Pracująca w sprawie agentura w okresie sprawozdawczym nie podała bardziej interesujacych wiadomości. Inwigilacja oficjalnych wystapień figuranta nic nowego do sprawy nie wniosta ${ }^{56}$.

Prowadzono w okresie sprawozdawczym, oprócz akcji „Nieznany” inną o kryptonimie "Michal” przeciwko o. Tadeuszowi Machejkowi podejrzanego o utrzymywanie kontaktów z b. pracownica MON ob. Bocheńska Maria, która byta rozpracowywana przez Zarzad I Głównego Zarzqdu Informacji WP pod zarzutem szpiegostwa w ramach sprawy agenturalnego rozpracowania krypt. „Kuna”. Sprawe jako bezpodstawnie prowadzona na Bocheńskq M. zlikwidowano. Z dalszego sprawozdania wynika, że o. Machejek i Bocheńska mieli wspólnych znajonych - rodzinę adwokata (przedwojennego sędziego) Kołdrasińskich z Białegostoku, których poznali w Zawoi. Sprawozdanie kończy się stwierdzenie: Dla sprawdzenia prawdomówności Machejka (z którym o znajomościach przeprowadzono stosowne rozmowy) wystano pismo do Biategostoku celem usyskania informacji o Kołdrasińskich i jeżeli opinia okaże się tak jak przedstawil ja figurant, sprawę na O. Machejka zlikwidujemy ${ }^{57}$.

We wrześniu 1958 roku referenci służb bezpieczeństwa w sprawozdaniu z pracy Grup V i Va Wydziału III Komendy Wojewódzkiej Milicji Obywatelskiej w Krakowie za okres trzeciego kwartału 1958 roku z satysfakcją pisali do naczelnika Wydziału V Departamentu III Ministerstwa Spraw Wewnętrznych w Warszawie: Postepy w prowadzonych sprawach. Sprawa agenturalno-sprawdzenia kryptonim "Nieznany”. Sprawa prowadzona jest na przeora Karmelitów Bosych w Krakowie o. Wojnicza podejrzewanego o ukrywanie sie pod fatszywym nazwiskiem. Ustalono prawdziwe nazwisko figuranta co stwierdzono poprzez informatora ps. „Bros” [?], który pozostaje na kontakcie Wydz. II-go KMMO na m. st. Warszawa. Dane te uzyskano w zwiazku z tym, ze wymieniony informator zna się z figurantem z okresu okupacji podczas wspólnego pobytu w Wilnie i obopólnie znajq swoja działalność z poprzedniego okresu. Informator podat, ze zna zakonnika karmelite bosego, który jest przetozonym w klasztorze w Krakowie a jest nim $\mathrm{Wa}$

${ }^{56}$ Tamże, Sprawozdanie z pracy Grup Vi Va Wydziatu III KWMO w Krakowie za okres II-go kwartatu 1958 roku do naczelnika Wydziatu V Departamentu III MSW w Warszawie, Kraków, 23 VI 1958 r. (ściśle tajne), s. 147.

${ }^{57}$ Tamże, s. 159-160. 
rakomski ps. "Hilary" pracownik komórki legalizacyjnej Biura Paszportowego przy komendzie AK Wilno, który w 1945 roku przybyl do Polski i ukrywat sie, bowiem byt poszukiwany w okresie procesu Komendy AK okregu wileńskiego. Warakomski ps. Hilary" wstapit do zakonu Karmelitów bosych pod fatszywym nazwiskiem Wojnicz Roman imię zak. "Marian" i do dziś pod tym nazwiskiem wystepuje. Ustalono równiez $w$ okresie sprawozdawczym, że figurant posiada rodzonego brata Warakomskiego Piotra ps. "Michat”, który podczas procesu wileńskiego zbiegt do Anglii a obecnie przebywa w Chicago i utrzymuje pośredni kontakt z figurantem przez Kielka Stanisława zam. we Wroclawiu [...]. Poza tym stwierdzono, ze figurant sprawy o. Wojnicz utrzymuje ożyione kontakty korespondencyjne $z$ osobami z okresu okupacji, które nalezaty do AK $i$ wspólnie z nim dziataty w tej organizacji: a/ Krówka Aleksandra zam. w Krakowie [...] b/ Kruk Janina ps. „Lid$k a "[\ldots]^{58}$.

W kolejnym sprawozdaniu, w grudniu 1958 roku, odnotowano: Sprawa agenturalnego sprawdzenia krypt. „Nieznany”. Do sprawy w listopadzie b.r. opracowano kolejny plan przedsięwzięć operacyjnych. W rezultacie jego realizacji mamy otrzymać potwierdzenie dokumentami oficjalnymi faktu, ze figurant używa fatszywego nazwiska. Następstwem tego, jak zakładamy, będzie ujawnienie figuranta, poniewaz za przestęsstwa polityczne, które popelnit w poprzednich latach nie moze być pociagany obecnie do odpowiedzialności. Przy realizacji planu przedsięwzięć w sprawie krypt. „Bosy” między innymi przeprowadzono rozmowę z figurantem. Okazat się on czlowiekiem takim, jak charakteryzowala go agentura. Później uzyskaliśmy dane, ze gdy otrzymat wezwanie na MO byt pewny, że to „w swojej sprawie". Mamy też niepotwierdzona informację, ze figuranta ktoś ostrzegt, podajac mu, że jego przeszłość jest znana $U B^{59}$.

Krakowskie służby bezpieczeństwa zajmowały się w 1958 roku nie tylko wspomnianym przeorem. Zapewne dzięki doniesieniom "Satyra” i "Sikorskiego" a także innych tajnych współpracowników pozyskano wiele "cennych materialów" obciążających karmelitów.

W okresie sprawozdawczym [grudzień 1958 roku] wszczęto sprawę agenturalno-śledcza krypt. „Bosy” na ob. Moskala Stefana pracownika Wydz. do Spraw Wyznań Prez. MRN w Krakowie, na podstawie uzyskanych agenturalnych materiatów od inf. ps. "Satyr" - mówiacych o tym, ze figurant wzią tapówke od $O O$. Karmelitów Bosych. Na zatozenie sprawy uzyskano zgodę WKKP przy KW PZPR gdyz ob. Moskal jest członkiem Partii. Po blizszym rozeznaniu agenturalnym, usilowalismy przestepstwo to udokumentować. W trakcie prowadzonych rozmów uzyskano czesściowe potwierdzenie materiatów agenturalnych, jednakże z uwagi na ich niepetność, nie mogły one stanowić podstawy do wszczęcia śledztwa. W zwiazku z tym sporzadzono z posiadanych materiatów odpowiednia notatke informacyjnq i przekazano Komisji Kontroli Partyjnej KW PZPR w Krakowie do rozpatrzenia sprawy z wnioskiem o usunięcie ob. Moskala z zajmowanego stanowiska ${ }^{60}$.

${ }^{58}$ Tamże, Sprawozdanie z pracy Grup V..., Kraków, 24 IX 1958 r. (ściśle tajne), s. 187-188.

${ }^{59}$ Tamże, Sprawozdanie z pracy operacyjnej Grup Vi Va Wydzialu III KWMO w Krakowie za okres IV-go kwartalu 1958 roku do naczelnika Wydzialu V Departamentu III MSW w Warszawie, Kraków, 27 XII 1958 r. (ściśle tajne), s. 226.

${ }^{60}$ Tamże, s. 224. 
W marcu 1959 roku sprawę zamknięto a w miesięcznym sprawozdaniu odnotowano: Sprawe agenturalno-śledczq krypt. „Bosy” prowadzona na ob. Moskala złożono w archiwum Wydziatu Ewidencji operacyjnej z uwagi na nieprzyznanie sie w. wymienionego do stawianych mu zarzutów, oraz braku możliwości przedstawienia odpowiednich dowodów. Opracowano natomiast szczególowa informacje w tej sprawie i przekazano do Komisji Kontroli Partyjnej KM PZPR w Krakowie ${ }^{6}$.

W omawianym okresie interesowano się wszelkimi poczynaniami przełożonych zakonnych. W jednym ze sprawozdań zachowała się informacja o karmelitach bosych: W zakonie tym prowincjat przeprowadzit ostatnio wizytacje. $W$ wyni$k u$ tej nastapily duże zmiany personalne. Wielu ojców, braci zostało poprzenoszonych do innych klasztorów na różnego rodzaju stanowiska. Zmiany te podyktowane sq podobno przepisami konstytucji, lecz nie zawsze tak jest. $N p$. w wypadku ojca Benedykta, który zostal przeniesiony do Lodzi, rzekomo dlatego, ze bardzo dlugo byt w Krakowie, a to byto niezgodne z konstytucja. Kulisy tego przeniesienia sa jednak inne. Mianowicie jak podaje inf. ps. ,,Satyr" a potwierdza równiez ps. ,, Sikorski" przeniesiony on zostat dlatego, bo ojciec Wojnicz - przeor klasztoru krakowskiego wysunqł przeciwko niemu podejrzenia, ze wspótpracuje w UB. W Łodzi ma on być poddany obserwacji i odizolowany od wazniejszych spraw zakonnych, by nie mógł zdradzać tajemnic wewnatrz zakonnych. Zdaniem Ojca W[ojnicza] Stużba Bezpieczeństwa w Krakowie jest wyjatkowo dobrze zorientowana w sytuacji panujacej w klasztorze OO. Karmelitów Bosych. Podobne podejrzenia wysuwa sie przeciwko jednemu z braci i pracownikowi cywilnemu klasztoru. Podejrzenia te zrodziły się po rozmowach jakie przeprowadzilissmy z kilkoma zakonnikami a między innymi i z przeorem. Rozmowy te mialy na celu potwierdzenie naszych informacji agenturalnych $w$ sprawie agenturalnej na osobę krypt. „Bosy” o czym mowa w pkt I niniejszego sprawozdania ${ }^{62}$.

W 1958 roku służby bezpieczeństwa interesowaly się także o. Danielem Rufeisenem. Krakowska SB prowadząc sprawę ewidencyjno-obserwacyjną na dominikanina o. Kasznicę ustaliła, że nawiązuje on kontakty z byłymi członkami AK i powstańcami warszawskimi. Przy okazji ustalono kontakty o. Kasznicy z o. Rufeisenem - o czym donosił w kwartalnym sprawozdaniu z pracy operacyjnej Grup V i Va Wydziału III KWMO w Krakowie mjr J. Gibski: Ustalono także ciekawy kontakt figuranta [o. Kasznicy] z O. Danielem - Karmelita Bosym. O. DanielRufeisen Oswald jest narodowości żydowskiej, b. członek organizacji syjonistycznej p.n. „,Akiba” oraz pracownikiem żandarmerii niemieckiej za okupacji. Z kolei w obawie przed aresztowaniem ucieka on do partyzantki radzieckiej a po wyzwoleniu wstepuje do zakonu. Kontakt między mini o tyle zashuguje na uwage, ze $O$. Daniel pozostaje w zainteresowaniu pewnych czynników za granicq, a także zamierza wyjechać do Izraela ${ }^{63}$.

${ }^{61}$ Tamże, Sprawozdanie z pracy operacyjnej Grup V... i Va Wydziału III KWMO w Krakowie za okres I-go kwartah 1959 roku do naczelnika Wydziatu V Departamentu III MSW w Warszawie, Kraków, 25 III 1959 r. (ściśle tajne), s. 287.

${ }^{62}$ Tamże, Sprawozdanie z pracy operacyjnej Grup V..., Kraków, 27 XII 1958 r. (ściśle tajne), s. 249-250.

${ }^{63}$ Tamże, Sprawozdanie z pracy operacyjnej Grup V..., Kraków, 24 IX 1958, s. 199-200, 
W latach 1959-1961 wielokrotnie cytowane wcześniej sprawozdania kierowane $z$ terenu województwa krakowskiego do Ministerstwa Spraw Wewnętrznych nie wspominają zbyt często o karmelitach bosych. Zapewne tajni współpracownicy służb bezpieczeństwa wywodzący się $\mathrm{z}$ omawianego środowiska opuścili Kraków - zostali przeniesieni do innych klasztorów, przebywali za granica, odmówili współpracy lub byli używani do rozpracowywania innych obiektów. W omawianym okresie prowadzono jedynie sprawę operacyjną na o. Romana Wojnicza ${ }^{64}$.

Funkcjonariusze służby bezpieczeństwa na nowo zainteresowali się karmelitami bosymi w 1962 roku. W sprawozdaniach rocznych za ten rok odnotowali, że zakonnicy zwracali się do wiernych pisemnie o przysyłamie intencji mszalnych. Ponadto odnotowano, że pisali do Polonii szwajcarskiej o pomoc materialną otrzymywali stamtąd lekarstwa i materiały ubraniowe. Paczki były przysyłane na prywatne adresy $\mathrm{w} \mathrm{kraju}^{65}$. W przeciwieństwie do okresu poprzedniego w latach sześćdziesiątych na wiele klasztorów i zakonników przebywających na terenie województwa krakowskiego nakładano kary pieniężne. Ten system „dręczenia” nie ominą karmelitów bosych. Kolegium Karno-Adm. ukarało grzywnq 1500 zt. o. Jabłonskiego Stanisława (karmelita bosy) za zorganizowanie nielegalnie procesji. Ponieważ sumy tej niechcial wplacić grzywne zamieniono na 40 dni aresztu i skierowano go do odbycia kary w $\mathrm{CW} w$ Krakowie. Po trzech tygodniach pobytu $w$ więzieniu klasztor wpłacit grzywnę i o. Jabloński zostat z więzienia zwolniony ${ }^{66}$.

$\mathrm{Na}$ początku 1962 roku wśród 24 tajnych współpracowników w Grupie Va Wydziału III m. in. był karmelita bosy: t.w. ps. „Stanisław” przeor, pochodzenie spot. chłopskie, pozyskany do wspótpracy przez Wydz. III-ci w Krakowie w miesiącu marcu 1960 r. Do wspótpracy chętny, często sam wywoluje spotkania. Jednostka cenna ${ }^{67}$. Kilka miesięcy wcześniej na temat „Stanisława” odnotowano: zwerbowany w 1959 r. na zasadzie lojalności, do wspótpracy chętny, spotkania odbywaja się na L.K., chociaz doniesień własnoręcznie nie pisze, jest cenna jednostka. Wynagradzany jest $w$ formie prezentów i pieniędzy. Pozostaje na kontakcie tow. Króla ${ }^{68}$.

Należy dodać, że w tymże okresie w środowisku krakowskim dominikanów było 2 tajnych współpracowników, paulinów -2 , zmartwychwstańców - 2, benedyktynów -1 , cystersów -1 , karmelitów bosych -1 , salezjanów -1 , karmelitów trzewiczkowych -1 , michalitów -1 , albertynów -1 , misjonarzy - 2 , bonifratrów

${ }^{64}$ Por. Tamże, sygn. 08/141, t. 2, Plan organizacyjny $i$ kierunkowy pracy Grupy Va $W y$ dzialu III-go KWMO w Krakowie opracowany przez kpt. P. Lebiedzia, Kraków, 10 XI 1961 r., s. 67.

${ }^{65}$ Por. tamże, t. 13, cz. 1, Sprawozdanie roczne [Grupy II Wydziału IV SB KWMO w Krakowie] za 1962 rok, Kraków, 20 XII 1962 r. (tajne), s. 8.

${ }^{66}$ Tamze, Sprawozdanie (wg wytycznych Gab. Min.) z dzialalności Gr. II Wydz. IV-go za 1962 r., Kraków, 2411963 r. (tajne), s. 11. Na temat o. Bazylego od św. Anzelma Stanisława Jabłońskiego zob. J. W a n a t, Jabloński Stanisław, [w:] Leksykon..., s. 93-94.

${ }^{67}$ IPNKr, sygn. 08/141, t. 1, Pismo naczelnika Wydzialu III-go kpt. Z. Faryny do naczelnika Wydziatu V Departamentu III-go MSW, Kraków, 26 IV 1962 r. (tajne, specjalnego znaczenia), s. 55 .

${ }^{68}$ Tamże, t. 2, Plan organizacyjny i kierunkowy pracy Grupy Va Wydzialu III-go KWMO w Krakowie opracowany przez kpt. P. Lebiedzia, Kraków, 10 XI 1961 r., s. 71. Por. tamże, Sprawozdanie z przeprowadzonej kontroli w Grupie II Wydzialu IV-go SB KWMO w Krakowie, Kraków, 24 III 1964 r., s. 197. 
1, nazaretanek - 1. Ponadto w powiatach byli tajni współpracownicy w powiatach: Chrzanów - 1 bernardyn, Wadowice -1 bernardyn, Limanowa - 1 cysters, Tarnów -1 redemptorysta, Nowa Huta -3 cystersów ${ }^{69}$. Natomiast kandydatami opracowywanymi przez Wydział III byli: karmelita trzewiczkowy - 1, pijar - 1, misjonarz - 1 , służebniczka starowiejska -1 , kanoniczka -1 , urszulanka $-1^{70}$.

Na przełomie lat 1962/1963 na kontakcie Wydziału IV Służby Bezpieczeństwa w Krakowie pozostawali wymienieni wcześniej: „Stanisław” oraz „Sikorski”. Były to - jak je określano - jednostki cenne ${ }^{71}$. Przy drugim $z$ wymienionych zapisano w nawiasie „nie zarejestrowany”. W 1963 roku na terenie województwa krakowskiego było 26 tajnych współpracowników spośród osób zakonnych ${ }^{72}$.

W roku 1962 władze bezpieczeństwa województwa krakowskiego zajmowały się szczegółowo życiem i działalnością wspólnot zakonnych. Oto jedna z charakterystyk: Zakon $O O$ Karmelitów Bosych nie prowadzi żadnego zakładu ani tez przedsiębiorstwa, a utrzymuje się z pracy na gospodarstwie rolnym $i$ ogrodowym oraz z datków ludności na tace jak $i$ zamawiajacych msze oraz z fundacji zakonu wyższego szczebla - prowincjałatu, którego siedziba mieści się w Katowicach. Klasztor nie prowadzi działalności charytatywnej, gdyż jest klasztorem zamkniętym, natomiast prowadzi dzialalność ideowo-wychowawcza wśród mlodych kleryków przyjezdżajacych rokrocznie do tego klasztoru w czasie rekolekcji oraz w kościele gdzie gromadzi się miejscowa ludność. OO. Karmelici prowadza także nauki stanowe i rekolekcje $w$ domu SS Karmelitanek w Czernej Nr 196 dla przyjeżdżajacych.

Nauki takie sq organizowane przeważnie $w$ porze letniej. W $1960 \mathrm{r} . \mathrm{w}$ ramach wielkiej nowenny organizowali wszelkiego rodzaju rekolekcje zamknięte oraz nauki stanowe trwajace od trzech do 6-ciu dni dla danego stanu. Nauki takie byty organizowane dla lekarzy, pielęgniarek, nauczycieli oraz kobiet $i$ dziewczqt. Na nauki te przyjeżdżly osoby z calego kraju. Należy przy tym nadmienić, ze

${ }^{69}$ Por. tamże, t. 1, Pismo naczelnika Wydzialu III-go..., Kraków, 26 IV 1962 r., s. 56-59.
${ }^{70}$ Tamże, s. 59.
${ }^{71}$ Na podstawie przeprowadzonej kontroli i analizy pracy z t.w. będqcych na tqczności Grupy II sytuacja przedstawia się nastepujaco: 1. T.w. ps. „Stanistaw" nr rej. $2409 / 62$ pozyskany 22 II 1960 r. na zasadzie dobrowolności, ksiadz zakonny, karmelita bosy. Wykorzystywany jest do rozpracowywania zakonu karmelitów bosych, w którym to zakresie posiada możliwości, jednakże nie w petni sq one wykorzystywane. Poza zakonem nie posiada większych możliwości. Przestrzega konspiracji, spotkania odbywane sq na LK .Chata". Na przestrzeni 1963 r. odbyto 11 spotkań. Jest jednostkq sprawdzonq $i$ zwiqzanq ze Stużbq Bezpieczeństwa. Pracuje w oparciu o piany, wynikajace z rozpracowania obieḱlowego. Ǩierunkowy pian pracy dia $t$.w. jest w trakcie opracowania. Jest wynagradzany w formie prezentów $i w$ gotówce. (Teczki znajduja się w Dep. IV MSW). Pozostaje na kontakcie st.ofic. oper. por. Króla. 2. T.w. „Sikorski” nr rej. 4730/64, pozyskany 25 I 1958 r. na zasadzie dobrowolności, ksiqdz zakonny, karmelita bosy, posiada możliwości operacyjne, jednakże materiaty podaje ogólno-informacyjne. W $1963 \mathrm{r}$. odbyto dwa spotkania, gdyż zostat on przejęty ponownie na kontakt z Dep. I. Spotkania odbywane sq na MK krypt. „Grota”. Jest jednostka sprawdzonq i zwiqzanq ze Stuzbą Bezpieczeństwa. W 1963 r. otrzymal z Wydz. IV 1000 zl. Plan pracy jest w trakcie opracowania. Pozostaje na taczności st. ofic. oper. por. Króla-tamże, sygn. 08/141, t. 2, Sprawozdanie z przeprowadzonej kontroli w Grupie II..., Kraków, 24 III 1964 r., s. 197.

${ }^{72}$ Por. tamże, t. 1, Zestawienie stanu agentury Grupy IJ Wydziału IV, Kraków, 6 I 1964 r. (tajne), s. 64 . 
w chwili obecnej do gromady Czerna dojeżdza PKS ze stacji Krzeszowice, co umożliwia uczestnikom takich rekolekcji szybkie dostanie się do gromady Czerna.

Należy przy tym nadmienić, ze zakon prowadzi nowicjat przygotowujac braci do klasztornego zycia, jak i tez zdolniejszych wysyłaja po roku do seminarium duchownego na studia teologiczne. Na przestrzeni lat poprzednich do chwili obecnej stwierdzono tylko jedno agresywne wystapienie przeciwko Wtadzy Ludowej ze strony zakonników. Należy przy tym również stwierdzić, że sa oni niepopularni wśród miejscowej ludności, a to z powodu pewnych machinacji w czasie sprzedaży gruntu okolicznym chtopom. Do chwili obecnej klasztor jest zadlużony wobec państwa w niepłaceniu podatku gruntowego i dochodowego ogótem na 120 tys. złotych. W chwili obecnej w klasztorze znajduje się 25 zakonników w tym 9-ciu ojców a 16-tu braciszków. Stan osobowy klasztoru nie jest nigdy stały, gdyz sq częste przeniesienia do innych klasztorów tak ojców jak i braci. Funkcje obecnego przetożonego klasztoru pełni ojciec Krzysztof - Król Stanislaw (jest on w operacyjnym zainteresowaniu Wydz. III-go KWMO Kraków).

Od $1961 \mathrm{r}$. w kościele klasztornym jest prowadzona nauka religii dla dzieci zamieszkałych w gromadzie Czernej. Klasztor ten nie prowadzi parafii, gromada Czerna podlega pod parafie Nowa Góra, jest to sasiednia gromada. Stosunki między proboszczem Nowa Góra a klasztorem nie uktadaja sie pomyślnie, sa częste tarcia na tle finansowym, gdyż większość mieszkańców Czernej uczęszcza do kościoła klasztornego, jak również zamawia też w klasztorze msze $[\ldots]^{73}$.

W dalszej części „charakterystyki” napisano: Kler katolicki tak świecki jak $i$ zakonny caty wysitek skierowat przede wszystkim na pozyskanie mtodzież. Takie fakty notuje się ze strony OO Karmelitów Bosych, którzy to OO pod płaszczykiem uprawiania pewnych dyscyplin sportowych jak n.p. granie w szachy skupiaja wokót siebie młodziez z catej okolicy i przy tak dogodnych warunkach prowadzq oni pewne wyklady o charakterze religijnym i tym samym wpajaja fanatyzm religijny mlodzieży. Dodać przy tym należy, ze OO Karmelici organizuja również pewne imprezy kościelne, jak n.p. jasetka, męki pańskie i tym podobne sztuki, do których to wykorzystuja mlodziez szkolna. Do tych celów wykorzystuja oni świetlice gromadzkq. Na jednym z głoszonych kazań przez o. Rufeisena przeprowadzit on analizę wykazujac, że w naszej prasie i radiu gtosi się, ze w Polsce istnieje dobrobyt a w rzeczywistości jest inaczej i uważa to za falsz $i$ klamstwo. Podajac przy tym, ze robotnik nie może wyzyć z rodzina za 18 zt swego dziennego zarobku. Poza tym OO. Karmelici na prowadzonych naukach stanowych dla lekarzy i pielęgniarek poruszajac przy tym ustawe o regulacji urodzin, wpajali w nich, ze oni za swa dziatalność sq odpowiedzialni w pierwszym rzędzie przed Bogiem, a potem przed narodem $[\ldots]^{74}$.

W dwa miesiące później ppłk J. Gibski w nawiązaniu do sprawozdania z Chrzanowa - zob. wyżej - pisał: Warto nadmienić, że nie wszystkie materiaty zamieszczone $w$ charakterystyce kontrwywiadowczej za rok 1961 polegaja na prawdzie. Np. na str. 19 jest podane, że o. Rufeisen na jednym z gloszonych kazań szkalowal obecnq rzeczywistość a faktycznie zakonnik ten od dwóch lat przebywa w Izraelu dokad wyjechat na pobyt staty. Podobnie cztery lata temu oo. karmelici

${ }^{73}$ Tamże, t. 2, Charakterystyka kontrwywiadowcza po zagadnieniu kleru zakonnego, Chrzanów, 30 I 1962 r. (tajne) [sporządził ppor. P. Zatyla], s. 235-237.

${ }^{74}$ Tamże, s. 252-253. 
bosi wykorzystywali miejscowa świetlice gromadzka do organizowania różnego rodzaju imprez o charakterze religijnym ${ }^{75}$.

Po zapoznaniu się z aktualnymi materiałami w odniesieniu do zakonów zalecono nizej wym. kierunek pracy: Klasztor OO Karmelitów Bosych w Wadowicach. Wg rozeznania agenturalnego klasztor $O O$ Karmelitów Bosych w Wadowicach przebywa okoto 14 księzy i 3 braci. Klasztor ten o tyle może być brany pod uwage w operacyjnym zainteresowaniu sie nim, że mieści się tu małe seminarium. $W$ małym seminarium pobiera nauke około 70 uczniów. Z seminarium tego karmelici zdobywaja narybek dla swego zakonu.

$W$ zwiqzku z powyższym wszelkie przedsięwzięcia nasze winny zmierzać do zdobycia materiałów, które dałyby podstawy do postulowania w kierunku likwidacji tegoż seminarium. Po zapoznaniu się z posiadanymi materiałami na zakonników z klasztoru OO Karmelitów Bosych w Wadowicach wydaje się za stuszne wykonanie następujacych przedsięwzięć:

a/ rozpoznać personel świecki-nauczycielski matego seminarium i z pośród tego personelu wytypować jednego kandydata do pozyskania w charakterze t.w. wzglednie P.O.

b/ przeprowadzić rozmowe z o. Szczurem im. zak. „Andrzej", który obecnie przebywa w Kluszkowcach, pow. Nowy Targ na kuracji. Zakonnik ten prawdopodobnie wystapi z zakonu. Ma bowiem nieporozumienia z kierownictwem zakonu. $W$ rozmowie $z$ nim, która powinna dać informacje o poszczególnych zakonnikach dażyć do ewentualnego pozyskania o. Szczura.

c/ zainteresować się zakonnikiem o. Szczesnym, który zajmuje się procesami beatyfikacyjnymi, w zwiazku z tym zachodzi u niego konieczność wyjazdów do Rzymu. Moze na tej plaszczyźnie można by dogadać się z nim. Dlatego postuluję przeprowadzenie z nim rozmowy.

d/ kontynuować rozmowy z przeorem o. Nowakiem "Maksym" - majac na celu pozyskanie go do wspótpracy ${ }^{76}$.

Po kilkumiesięcznej przerwie w 1963 roku karmelici bosi ,powrócili” na łamy sprawozdań. Szef Wydziału IV SB w Krakowie informował swych przełożonych, że $o$. Ludowich Tadeusz ze zgromadzenia karmelitów bosych utrzymuje stały kontakt korespondencyjny z dwoma osobami zamieszkatymi na terenie NRF-u. W korespondencji przedstawia falszywy obraz stosunków Państwo-Kościo ${ }^{77}$.

W tym samym sprawozdaniu znajduje się jeszcze jedna informacja dotycząca karmelitów bosych, tym razem dotycząca zakonników z Czernej. Konflikt między oo. karmelitami bosymi w Czernej a ekonomem parafii Paczółtowice ks. Królem. Pod nieobecność ks. Króla, który w 1963 r. przebywat w USA karmelici rozpoznali sytuacje w parafii oraz osobowość ks. Króla. Na skutek redagowania przez nich szkalujacych anonimów, kuria krakowska postanowita przenieść ks. Króla na inna parafię. Usiłowania RSB Chrzanów szły w kierunku wykorzystania

${ }^{75}$ Tamże, Pismo naczelnika Wydziału III-go pplk. J. Gibskiego do z-cy komendanta Powiatowego MO SB w Chrzanowie, Kraków, 9 III 1962 r., s. 259

${ }^{76}$ Tamże, Notatka sluzbowa z pobytu slużbowego w Ref. St. Bezp. KPMO w Wadowicach, Wadowice, 23 II 1962 r. [sporządzona przez kierownika Grupy Va Wydziału III Lebiedzia], s. 261.

${ }^{77}$ Tamże, sygn. 039/1, t. 12, Sprawozdanie z pracy operacyjnej Wydzialu IV..., Kraków, 9 I 1965 r. (tajne specjalnego znaczenia), s. 79. 
zaistnialego konfliktu dla utworzenia Niez. Par. Cel ten nie zostat jednak osiagnięty z uwagi na to, że zarzqdzeniem kurii dot. przeniesienia ks. Króla zostało cofnięte, a ponadto on sam nie wyrażat chęci na podjęcie dzialalności zmierzajacej do utworzenia niezależnej parafii ${ }^{78}$.

W podsycanie konfliktu zaangażowani byli funkcjonariusze SB z Chrzanowa, którzy na wszelkie sposoby starali się ukazać karmelitów bosych miejscowej ludności w bardzo złym świetle. Potwierdza to sprawozdanie Komendy Powiatowej MO w Chrzanowie sporządzone w grudniu 1964 roku: dane te w umiejętny sposób przekazano wiernym, którzy byli po stronie OO. Karmelitów, że to $0 O$. Karmelici prowadzq destrukcyjnq działalność w parafii podrywajac tym samym ich opinie w oczach wiernych ${ }^{19}$.

Aparat bezpieczeństwa szczególną uwagę zwracał na działalność finansową zakonników. W jesieni 1963 roku krakowska SB informowała centralę w Warszawie, że Kamedula [!] bosy z Krakowa ul. Rakowicka 18 o. Rudolf Waczecha masowo rozsyła do wiernych $w$ całym kraju specjalne druczki, aby ludność nadsyłała pieniqdze na intencje tzw. wypominków za zmarlych ${ }^{80}$. W tym samym raporcie zaznaczono, że klasztor karmelitów bosych w Krakowie ul. Rakowicka 18 zalega w ptaceniu podatku dochodowego jeszcze za rok $1960^{81}$.

W 1964 roku w wyniku glębszego rozpracowania zakonu OO. Karmelitów Bosych ustalono, ze o. Jarosz z placówki w USA przybyt do Polski celem werbunku ojców na wyjazd do USA dla zasilenia tamt[ejszej] placówki. Placówka ta $w$ zamian przekazuje korzyści materialne dla działajacych $w$ kraju. Ostatnio ma przekazać 7 tys. dolarów na cele wydawnicze ${ }^{82}$.

Plany służące rozpracowaniu zakonów byly wykonywane przez funkcjonariuszy służby bezpieczeństwa $\mathrm{z}$ wielką precyzja, rozmachem i ze znajomością wielu wewnętrznych problemów danych wspólnot. Oto przykład: Karmelici bosi i trzewiczkowi - w zwiqzku z tendencjami do zjednoczenia tych 2 zakonów, o czym ma się opowiedzieć kapituta generalna w 1965 r. dla poglębienia rozeznania opracować 2 kandydatów krypt. „Uczen'” $i$,Irys" $i$ dokonać pozyskania jednego z wymienionych. Ponadto w oparciu o informacje od t.w. "Sikorski" i t.w. "Stanistaw" dobrać i opracować 2 kandydatów na t.w. majacych perspektywy zajęcia stanowisk wyższych przelożonych. Wykona por. H. Król w terminie do dnia $30 \mathrm{~V} 1965$ roku ${ }^{83}$.

W 1965 roku w sprawozdaniu grupy operacyjnej znalazło się stwierdzenie: $w$ wyniku analizy sieci $t$ [ajnych] $w$ [spółpracowników] wypracowano właściwe kierunki pracy co przy należytym kierowaniu przyczyniło się do pogłębienia pracy operacyjnej. Postępy na tym odcinku sq szczególnie widoczne w odniesieniu do zakonu jezuitów, bernardynów, dominikanów, franciszkanów, misjonarzy, karmelitów bosych i trzewiczkowych, gdzie w porównaniu z poprzednim okresem nastq-

\footnotetext{
${ }^{78}$ Tamże, s. 86-87.

79 Tamże, t. 14, Sprawozdanie [KP MO w Chrzanowie] za rok 1964 po zagadnieniu Wydzialu IV-go, Chrzanów, XII 1964 r. (tajne), s. 149.

${ }^{80}$ Tamże, sygn. 08/141, t. 1, Opinia ,Zakony i zgromadzenia zakonne męskie [w województwie krakowskim], Kraków, 30 XI 1963 r.", s. 383-393.

${ }^{81}$ Tamże, s. 392.

${ }^{82}$ Tamże, sygn. 039/1, t. 13, cz. 1, Sprawozdanie z pracy operacyjnej Grupy II Wydzialu IV-go za rok 1964, Kraków, 31 XII 1964 r. (tajne specjalnego znaczenia), s. 79.

${ }^{83}$ Tamże, sygn. 08/141, t. 2, Problemowy plan pracy Grupy II Wydziatu IV SB na 1965 rok, Kraków, 10 I 1965 r., s. 121.
} 
pila znaczna poprawa $w$ dotarciu do kierownictwa prowincji. Wykorzystujac posiadane możliwości operacyjne w zasadzie na biezaco kontrolowana jest działalność zakonów co ma odbicie w przesytanych meldunkach informacyjnych i licznych materialach [?] do Departamentu $I V$-go ${ }^{84}$.

W sprawozdaniu sporządzonym w styczniu 1964 roku zaznaczono, że t.w. „Toranto" i ps. „Sikorski” zrealizowat zadania jakie przed nim postawit Departament IV $[\ldots]^{85}$. Należy dodać, że $w$ miesiq̨cu grudniu $1963 \mathrm{r}$. podjęto ponownie na kontakt tw. ps. „Sikorski”, który przebywał przez kilka lat [...] pozostajac na kontakcie Dep. I-go MSW ${ }^{86}$. Za swoją działalność "Sikorski” otrzymywał zapłatę bądź to w gotówce, bądź to w postaci prezentów. Można to wnioskować ze sprawozdania za 1964 rok, w którym odnotowano, że podniesiono walory tw [...] ,. Sikorski" ${ }^{87}$.

Służby bezpieczeństwa interesowały się wszelką działalnością karmelitów bosych. Skrupulatnie sprawdzano $\mathrm{m}$. in. korespondencję wychodzącą z klasztoru. Zajmowała się tym komórka operacyjna oznaczona kryptonimem „W”. Funkcjonariusze SB z Wadowic donosili w rocznym sprawozdaniu za 1965 rok: w klasztorze OO. Karmelitów Bosych w Wadowicach znajduje się NSD, w którym wg dokumentu , W" nauczanie odbywa się niejednokrotnie przy nie przestrzeganiu tolerancji religijnej. Autorzy wspomnianego dokumentu, którymi sq alumni NSD: Jerzy Czajkowski, Jan Dziewulski i Zenon Wiktorko - piszac list do Przewodniczqcego Stowarzyszenia „Pax" B. Piaseckiego uskarżaja się, że w seminarium wychowuj się młodzież w duchu wrogości do obecnych władz, krytykuje się postępowe organizacje katolickie w kraju i stosuje się niedozwolone metody wychowania - wyrazajace się w biciu alumnów przez o. Cecyliusza. Alumni Czajkowski i Dziewulski wystapili z seminarium $i$ przeprowadzono z nimi rozmowy potwierdzily prawdziwość powyższych (informacja $z$ dnia 9.12 .1965 r.) ${ }^{88}$.

$\mathrm{Z}$ tego samego źródła pochodzi informacja, że o. Latuszek Stanislaw z klasztoru OO. Karmelitów Bosych w Wadowicach utrzymuje kontakt korespondencyjny z uciekinierem ks. Biernat Henrykiem przebywajacym obecnie w Pary$\dot{z} u^{89}$ oraz, że o. Ludowich Tadeusz - Jan z klasztoru OO. Karmelitów Bosych w Wadowicach koresponduje z ks. Dobrzańskim Michatem i Socik Halina którzy zam. na terenie RFN. O. Ludowich Tadeusz w swych listach do ks. Dobrzańskiego informuje o sytuacji kleru w Polsce - zwracajac uwage na duze podatki, jakimi obciqza się duchowieństwo. O. Kluz Mieczystaw - Wiktor z klasztoru OO. Karmelitów Bosych w Wadowicach utrzymuje taczność korespondencyjna z ks. Jarosz Johnem-przebywajacym w USA. W jednym z listów o. Kluz pisze w przenośni, że

${ }^{84}$ Tamże, sygn. 039/1, t. 13, cz. 1, Sprawozdanie z pracy operacyjnej [Grupy II Wydziału

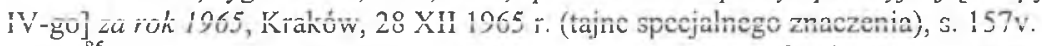

${ }_{85}$ Tamże, t. 12, Sprawozdanie z pracy operacyjnej Wydzialu IV SB KWMO w Krakowie za rok 1963, Kraków, 14 I 1964 r. (tajne specjalnego znaczenia), s. 45.

${ }^{85}$ Tamze, t. 13, cz. 1, Sprawozdanie z pracy operacyjnej Gr. II Wydz. IV-go za rok 1963, Kraków, 6 I 1964 r. (tajne), s. 24.

${ }^{87}$ Tamze, t. 12, Sprawozdanie z pracy operacyjnej Wydzialu IV SB KWMO w Krakowie za rok 1964, Kraków, 9 I 1965 r. (tajne specjalnego znaczenia), s. 74. Por. tamże, t. 13, cz. 1, Sprawozdanie z pracy operacyjnej Grupy II Wydzialu IV-go za rok 1964, Kraków, 31 XII 1964 r. (tajne specjalnego znaczenia), s. 79.

${ }^{88}$ Tamże, t. 13, cz. 2, Wyciag ze sprawozdania rocznego RSB Wadowice sporzadzone po pionie Wydziatu IV-go, Wadowice, 30 XII 1965 r. (tajne), s. 384.

${ }^{89}$ Tamże, s. 385. 
wokót księży jest „,burza”, lecz sq spokojni o ,jutro”. Jakkolwiek powyższe kontakty nie wskazuja na to, ze istnieje zagrożenie prowadzenia dzialalności szpiegowskiej, to jednak sa godne zainteresowania ${ }^{90}$.

W dalszej części rocznego sprawozdania Referatu Służby Bezpieczeństwa w Wadowicach, omawiając działalność profilaktyczną Wydziału IV, sprawozdawca nadmienił, że przeprowadzono rozmowę profilaktyczną $z$ o. Stanisławem Klimczakiem z uwagi na niedopełnienie formalności meldunkowych. Relator informował także swych zwierzchników, że w ścisłym kontakcie z klasztorem karmelitów w Wadowicach pozostają: Bogumiła Wider - sekretarka w Liceum Ogólnokształcacego w Wadowicach oraz Stefania Sikora - maszynistka w szpitalu w Wadowicach ${ }^{9 !}$. Informacje o kobietach, które współpracowały z karmelitami bosymi nie były przypadkowe. Bezpieka mogła je wykorzystać jako współpracowniczki, prowokatorki, pomoce obywatelskie albo też przedstawić jako „przyjaciółki karmelitów". Tak często postępowano dla kompromitacji moralnej zakonników. Ciągle też poszukiwano nowych sił do agentury zajmującej się karmelitami bosymi. Wiele wysiłku poświęcano na pozyskanie samych zakonników; których uprzednio, po wnikliwym rozeznaniu, typowano na kandydatów na werbunek. Jednym z nich był „Wychowawca”. Oto jego charakterystyka: Krypt. „Wychowawca" Nr 5742/65, wszczęto 9 VIII 65, duchowny zakonny, lat 33, wykształcenie WSD, katecheta. Celem pozyskania jest zapewnienie dopływu informacji z prowincji OO. Karmelitów bosych gdzie posiada bezpośrednie dotarcie. Materiały wskazujq ze jest on lojalnie ustosunkowany do wtadz państwowych i posiada sktonności do zycia świeckiego. Opracowywany jest w oparciu o plan przy wykorzystaniu t.w. "Sikorski”. Dotychczas nie nawiazano kontaktu z kandydatem, istnieja przesłanki na pozyskanie, dlatego też należy aktywniej przystapić do opracowywania. Opr. prowadzi por. Król $\mathbf{l}^{22}$. Starano się także pozyskać o. Pateckiego, któremu założono tzw. „teczkę na księdza” i którego wytypowano do aktywnego rozpracowania ${ }^{93}$.

O szczególnym zainteresowaniu służb bezpieczeństwa powiatu wadowickiego, działających pod szczególną kontrolą funkcjonariuszy wojewódzkich, tamtejszym klasztorem karmelitów bosych może świadczyć także urzędowa adnotacja stwierdzająca, że w dniu 6 grudnia 1964 roku, z okazji dnia św. Mikołaja, telefonistki z Urzędu Telekomunikacji w Wadowicach otrzymały od karmelitów bosych paczki ze słodyczami. W dalszej części relacja znalazła się informacja, że kierowniczka centrali należy do Trzeciego Zakonu Karmelitańskiego a telefonistki podsłuchują rozmowy działaczy PZPR, a także funkcjonariuszy Komendy Powiatowej MO i pracowników Rady Narodowej oraz innych instytucji i wiadomości przekazują do klasztoru ${ }^{94}$.

W innym ze sprawozdań, w cztery lata później (1968 rok), odnotowano, że karmelici bosi z Czernej posiadaja swych działaczy w środowisku świeckim, szcze-

${ }^{90}$ Tamże, s. 386.

${ }^{91}$ Por. Tamże, s. $390-391$

92 Tamże, sygn. 08/141, t. 2, Analiza problemów pracy operacyjnej zgodnie z zarzadzeniem $\mathrm{Nr}$ 8/65 z-cy Kom. Woj. MO ds. B w Grupie II Wydziatu IV-go, [Kraków, 1965 lub później], s. 170.

${ }_{93}$ Por. Tamże, Problemowy plan pracy Grupy II Wydzialu IV SB na 1965 rok, Kraków, 10 I 1965 r., s. 124.

${ }^{94}$ Por. Tamże, sygn. 039/1, t. 14, Sprawozdanie Referatu SB KPMO w Wadowicach po zagadnieniach pozostajacych $w$ zainteresowaniu Wydzialu IV-go za rok 1964, Wadowice, 28 XII 1964 r. (tajne), s. 408. 
gólnie infiltrują środowiska lekarskie i pielęgniarskie oraz administracji technicznej. Zaznaczono, że dziatalność ta prowadza zakonnicy w porozumieniu z kardynatem Wojtyta $^{95}$. Interesowano się także reaktywowanym w 1957 roku karmelitańskim Niższym Seminarium Duchownym w Wadowicach, które decyzją władz Prezydium Wojewódzkiej Rady Narodowej zniesiono w 1952 roku $^{96}$. W lutym 1968 roku naczelnik Wydziału IV Komendy Wojewódzkiej MO w Krakowie relacjonował do naczelnika Wydziału IV Departamentu IV MSW w Warszawie: Na marginesie ewentualnych zamiarów przejęcia bądź zlikwidowania NSD pragnę zaznaczyć, że jedynie Niższe Seminarium Duchowne Karmelitów Bosych w Wadowicach mogłoby zostać zakwalifikowane do tych celów - pozostałe dwa [bernardynów w Kalwarii Zebrzydowskiej i reformatów w Wieliczce] nie, z uwagi na nieodłqczność i zwiqzanie funkcjonalnie z obiektami klasztornymi, na terenie których się znajduja ${ }^{97}$.

W międzyczasie, w 1966 roku, Kościól katolicki w Polsce obchodził tysiąclecie chrztu Polski. Uroczystości milenijne urządzali także karmelici bosi w Krakowie. W dniu 23 listopada 1966 roku zorganizowali uroczystość w swoim kościele przy grobie br. Alberta Chmielowskiego z udziałem biskupa. Była to realizacja programu nakreślonego przez abpa Karola Wojtyłę znanego jako „Krakowski szlak tysiąclecia chrztu". W organizowaniu uroczystości millenijnych karmelici bosi byli spośród zakonów jedną z najaktywniejszych wspólnot ${ }^{98}$.

Pod koniec lat sześćdziesiątych ukazało się rozporządzenie dotyczące aktualizacji ewidencji całej sieci tajnych współpracowników wywodzących się ze zgromadzeń zakonnych. Polecano aby do dnia 30 listopada 1969 roku nadesłać następujące dokumenty:

1. Wykazu $t$ [ajnych] $w$ [spółpracowników] $i$ kandydatów na tw, zawierajacego nastepujace dane: pseudonim; date pozyskania lub wszczęcia opracowania kandydata; nazwe zgromadzenia, którego jest członkiem; na czyim pozostaje kontakcie lub przez kogo jest opracowany - jednostka i nazwisko pracownika; ewentualne uwagi.

2. Charakterystyki tw uwzgledniajace: al dane osobowe i oceny osobowości: wiek; pseudonim; wyksztatcenie; czasookres pobytu w zakonie; pozycja w zgromadzeniu i perspektywy; zainteresowania; inteligencja; spostrzegawczość; zaradność; elokwencja; odwaga; umiejętność nawiazywania kontaktów; matomówny, czy gadatliwy; postawa moralna; skruputy; b/ ocena przydatności operacyjnej: stopień zaangażowania we wspótpracy $z$ org. $S B$; możliwość wykorzystania do specjalnych zadan'; czy przejawia inicjatywe w uzyskiwaniu informacji, dokumentów oraz $w$ realizacji zadań; stopień przestrzegania zasad konspiracji; podejmowane czynności sprawdzajace $i$ ich wynik; jak jest aktualnie wykorzystywany ${ }^{99}$.

Aktualizacja sieci agenturalnej była spowodowana wcześniejszymi utyskiwaniami SB na brak źródeł informacji o wspólnotach zakonnych, na trudności

${ }^{95}$ Tamże, t. 16, Sprawozdanie [KPMO w Chrzanowie] dla naczelnika Wydzialu IV-go KWMO SB w Krakowie [za rok 1968, Chrzanów, 20 XII 1968 r. (tajne), s. 100.

${ }^{96}$ Por. B. J. W a n a t, Zakon karmelitów bosych $w$ Polsce. Klasztory karmelitów i karmelitanek bosych. 1606-1975, Kraków 1979, s. 587.

${ }^{97}$ IPNKr, sygn. 08/141, t. 1, Pismo naczelnika Wydzialu IV KW MO w Krakowie do naczelnika Wydzialu IV Departamentu IV MSW w Warszawie, Kraków, 26 II 1968 r., s. 162.

${ }^{98}$ Por. tamże, Informacja dot. udziału zakonów i zgromadzeń zakonnych męskich i żeńskich w uroczystościach milenijnych [Kraków, 1966], s. 667-668, 671.

${ }_{99}$ Tamże, Pismo z-cy naczelnika Wydziatu I Departamentu IV MSW ptk. S. Mozala do do naczelnika Wydzialu IV SB KW MO w Krakowie, Warszawa, 31 X 1969 r. (tajne), s. 6-7. 
w pozyskiwaniu nowych współpracowników i problemami z dawniejszymi konfidentami, którzy nie chcieli współpracować ${ }^{100}$.

Pisma polecające aktualizację rozsyłano do zastępców komendantów powiatowych MO Służby Bezpieczeństwa. W odpowiedzi, z Referatu Służby Bezpieczeństwa w Chrzanowie, przysłano stosowne wykazy tajnych współpracowników pozostających na kontaktach i w opracowaniu powiatowych jednostek Służby Bezpieczeństwa sporządzone w grudniu 1969 i styczniu 1970 roku. Wśród nich był $\mathrm{m}$. in. karmelita-tajny współpracownik ukrywajacy się pod pseudonimie „Włodek" pozyskany do współpracy w sierpniu 1969 roku $^{101}$. Oto jego charakterystyka: Na kontakcie RSB Chrzanów pozostaje aktualnie dwóch zakonników. Obaj jednak nie przebywajq na naszym terenie. [...] ,Wtodek" zostat pozyskany $w$ dniu 9.08.1969 r. [...]. W Zakonie cieszy się dobrq opiniq u przeora z racji wykonywanych funkcji w klasztorze styka się $z$ wieloma zakonnikami [...]. Z natury jest czlowiekiem spostrzegawczym, interesuje sie życiem zakonnym, posiada łatwość nawiazywania kontaktów z ojcami i braćmi, w rozmowach ostrożny, zrównoważony, pod względem moralnym bez zastrzeżeń. Nie ma zbytnich skrupułów gdy przekazuje SB informacje z caloksztaltu zycia zakonnego. Krótki okres kontaktów t.w. ze SB nie pozwoli na petnq ocene jego stopnia zaangażowania i możliwości $w$ wykonywaniu zadań. Należy stwierdzić, ze ze zleconych mu dotychczas zadań wywiqzal się precyzyjnie, z pelna odpowiedzialnościq, zachowując przy tym należyty stopień konspiracji $[\ldots]^{102}$.

Koniec lat sześćdziesiątych, kryzys gospodarczy, zawirowania polityczne powstałe w 1968 roku i walka polityczna w elitach władzy nie zmieniły metod działania SB. Regularnie penetrowano środowisko zakonne, postawy zakonników i ich stosunek do kleru diecezjalnego. Świadczy o tym poniższy fragment raportu opracowanego przez krakowski Wydział IV: Stosunek kleru zakonnego i kleru świeckiego w pewnym sensie uzewnętrznit przebieg wyborów do rady kaptańskiej w archidiecezji krakowskiej, jakie odbyty się wiosna 1969 r. Juz samo ułożenie zasad wyborczych dopuszczajqce do udzialu w wyborach wytacznie tych zakonników, którzy zatrudnieni sq w pracy duszpasterskiej, wywolato wiele krytycznych uwag a nawet opuszczania sali obrad, jak to miato miejsce w wypadku przeora karmelitów bosych o. Czecha. W wyniku wyborów do rady kaplańskiej nie wszedt żaden zakonnik, na 24 wybieranych czlonków rady kaplańskiej. Postawienie przez kard. Wojtylę w przepisach zarzqdzajacych wybory, iż należy wybierać proboszcza, wikarego lub innych księży w tym zakonnika przesądzilo wyniki wyborów na rzecz księży świeckich ${ }^{103}$.

${ }^{100}$ Por. Tamże, Protokót z narady partyjno-roboczej odbytej $w$ dniu 25 kwietnia 1967 roku w Grupie II Wydziatu II, s. 651-652.

${ }^{101}$ Por. tamże, Pismo naczelnika Wydziału IV SB KWMO [J. Chojnackiego] do naczelnika Wydzialu I Departamentu IV MSW w Warszawie, Kraków, 9 III 1970 r. (tajne specjalnego znaczenia), s. 16 20. Toż: Tamże, Pismo z-cy komendanta MO ds. SB w Chrzanowie pplka A. Ćwika do naczelnika Wydziału IV-go KW MO SB w Krakowie, Chrzanów, 13 XII 1969 r. (tajne), s. 47.

${ }^{102}$ Tamże, Pismo z-cy komendanta Powiatowego MO pplka A. Ćwika do naczelnika Wydziału $V$-go KWMO SB, Chrzanów 13 XII 1969 r. (tajne), s. 47; J. M a r e c k i, Wykaz wspótpracowników..., s. 15.

${ }^{103}$ IPNKr, sygn. 08/141, t. 1, Opinia ,Jak uktadajq się stosunki między świeckq hierarchiq kościelnq a zakonami $i$ ich kierownictwem [w województwie krakowskim]", Kraków, 1969 r. Referat opracowany przez Wydzial IV, s. 574-574. 
Powyższy tekst jest pierwszą próbą ukazania metod działania wszechwładnego aparatu bezpieczeństwa PRL wobec znanego i powszechnie szanowanego zakonu, jakim byli karmelici bosi. Klasztory w Krakowie, Czernej i Wadowicach należały do aktywnych ośrodków życia zakonnego i duszpasterskiego. Dla funkcjonariuszy UB (później SB) klasztory karmelitańskie były tylko obiektami „do rozpracowania", ośrodkami wrogiej propagandy i miejscem przebywania osób nieprzychylnych ustrojowi PRL. Walka z zakonami i zgromadzeniami zakonnymi stanowiła tylko niewielki fragment działalności wspomnianych służb w ich zwalczaniu Kościoła katolickiego i umacnianiu reżimu władzy ludowej. Metody działania służb bezpieczeństwa w PRL mimo dostępu do materiałów, które były ich warsztatem pracy, ciągle są mało znane. Autor ma nadzieję, że powyższy tekst przyczyni się zarówno do przybliżenia czytelnikom tej kwestii oraz dziejów najnowszej historii karmelitów bosych na ziemiach polskich.

\section{Discalced Carmelites as Focus of Attention of Polish People's Republic Security Force in Cracow Voivodship in the Light of Preserved Reports Sent to Ministry of Public Security and Ministry of Internal Affairs in the Years 1947-1970 Summary}

In the times of the Polish People's Republic, national security issues and, at the same time, surveillance of the society and suppression of many institutions - the Catholic Church included - were in the hands of appropriate services, modelled on the Soviet NKVD. At first this was the Ministry of Public Security and since 1956 the Security Police. The first part of the article presents the organization of security units in the voivodship of Cracow and the distribution of monastic communities, while the second throws light on the activities of these units on the basis of preserved reports sent from Cracow to the Ministry of Public Security and the Ministry of Internal Affairs. Officials of the Security Police who worked in the voivodship and district departments took a close interest in the Discalced Carmelite monks, taking account of their wartime past, pastoral activity and connections with the Church hierarchy. To ensure influence upon the life of the Discalced Carmelite Province as well as access to information on monastic internal issues they gained several secret collaborators within the congregation itself and its lay associates. The article is the first attempt at showing the methods of the Security Police (SB) and the Security Office (UB) activities directed at monastic orders; methods aiming at subjugating to the authorities not only the orders themselves, but the whole Catholic Church in Poland. 